\title{
Banking sector concentration, competition and financial stability: the case of the Baltic countries
}

\author{
Juan Carlos Cuestas* ${ }^{*}$ Yannick Lucotte ${ }^{\dagger}$ Nicolas Reigl $^{\ddagger}$
}

March 1, 2019

\begin{abstract}
This paper empirically assesses the potential nonlinear relationship between competition and bank risk for a sample of commercial banks in the Baltic countries over the period 2000-2014. Competition is measured by two alternative indexes, the Lerner index and the market share, while we consider the Z-score and loan loss reserves as proxies for bank risk. In line with the theoretical predictions of Martinez-Miera and Repullo (2010), we find an inverse U-shaped relationship between competition and financial stability. This then means that above a certain threshold, the lack of competition is likely to exacerbate the individual risk-taking behaviour of banks, and could be detrimental to the stability of the banking sector in the Baltic countries. The threshold is around 0.60 for the Lerner index, and close to $50 \%$ for market share in terms of assets. The policy implications are that the existence of such a threshold suggests that the future evolution of the structure of the banking industry in these countries is of critical importance. Specifically, this implies that policy-makers should place greater emphasis on mergers and acquisitions to avoid any significant increase of banking sector concentration.
\end{abstract}

Keywords: Bank competition, Banking sector concentration, Market power, Lerner Index, Financial stability, Bank-risk taking, Baltic countries JEL Codes: G21, G28, G32, L51

\footnotetext{
*Jaume I University, Eesti Pank. Email: Cuestas@uji.es

${ }^{\dagger}$ PSB Paris School of Business, Department of Economics, 59 rue Nationale, 75013 Paris, France. Corresponding author. Email: ylucotte@gmail.com

${ }^{\ddagger}$ Eesti Pank. Email: nicolas.reigl@eestipank.ee

This paper was written while Yannick Lucotte was a visiting researcher at the Bank of Estonia. He would like to thank the Bank of Estonia for its hospitality and financial support. We also thank Dmitry Kulikov, Aurélien Leroy, Jaanika Meriküll, Tairi Rõõm, and Karsten Staehr for their comments and suggestions. The views expressed in this paper are those of the authors and do not necessarily represent the official views of Eesti Pank or the Eurosystem. Any remaining errors are ours.
} 


\section{Introduction}

After the collapse of Lehman Brothers in the US in 2008, and the consequent need for a number of European banks to be bailed out, there has been concern recently about the relationship between banking sector concentration and financial stability within a country.

A number of studies have attempted to answer whether highly concentrated banking markets have an impact on financial stability. However, the results are far from conclusive since they vary with the period and countries analysed. The importance of a healthy banking sector for the successful functioning of an economy makes this subject topical for academics and policy-making institutions alike. Proper analysis of the degree of causality from banking concentration to banking sector stability can help institutions deploy the right measures to enhance stability, while it is a priority for academics to investigate how to measure banking competition and financial stability, and how to help policy-making promote stability and economic growth. Basic industrial organisation theory assumes that competition in markets tends to reduce the prices paid by consumers and increases efficiency, as only the most efficient firms could survive in a perfect competitive market. However, this prevailing assumption might be misguided for the banking sector, since fierce competition among banks can result in increased instability in the banking sector, leading to a financial crisis with fatal consequences for the banks. In this scenario, pro-competition policies that are targeted to enhance the efficiency of the financial sector might have strong adverse effects for the whole economy. Whether they do or not depends on whether tight competition enhances or reduces financial stability. The empirical literature does not provide a clear answer to this question, and theoretical papers do not reach a consensus either. This highlights the importance of establishing what the effect of bank competition on the risk-taking behaviour of financial institutions is, and then what its effect on financial stability is.

The literature offers two opposing views of the relationship between competition in the banking sector and financial stability (see, for instance, Beck, 2008). These views are the traditional "competition-fragility" view, and the "competition-stability" view.

The competition-fragility view argues that high levels of competition in the banking sector may increase financial instability and the fragility of banks. In a highly competitive banking sector, bank managers may have an incentive to take on high-risk operations in the search to make big profits quickly to meet profit objectives. This may lead them to put together a riskier portfolio of assets, which may end up in bankruptcies if there is a case of financial distress (see Keeley, 1990 amongst others for a theoretical model). In contrast, a less competitive environment where banks can afford higher capital buffers and less aggressive operations means the incentive to take increased unnecessary risk diminishes, enhancing the stability of the banking sector overall. Bergantino and Capozza (2013) say that bigger banks can afford to give low interest rates to new start-ups and share future profits. In addition, it is easier for the financial authorities to 
monitor a banking sector with fewer and bigger banks. Finally, bigger banks with a higher level of market concentration can access better conditions in international markets than they can find in domestic ones, making them able to lend more cheaply and reducing the cost of capital for firms and households (Beck et al., 2006).

The competition-stability view claims, on the contrary, that if a reduced number of banks have greater market power, it may increase the risks to their portfolios, as they will tend to set higher margins on loan interest rates. In this case, clients will have to pay a higher cost for borrowing, which may make nonperforming loans more likely to increase in number. Linked to this, increased competition may affect the cost of capital, giving firms and individuals access to lower interest rates, which would boost the profitability of investment projects, thus reducing credit risks and ultimately enhancing financial stability. In addition, big banks may believe that they are "too big to fail", which comes from the moral hazard effect of the authorities providing bailouts when problems arise (Mishkin, 1999). In this case a lack of competition may give banks an incentive to engage in riskier operations.

Our analysis in this paper focuses on the relationship between the competition and concentration in the banking sector and financial stability in the Baltic countries, which are Estonia, Latvia and Lithuania. The Baltic countries are a textbook example of an area with a highly concentrated banking sector, with a small number of large, mostly foreign, banks. In figure 1 we illustrate the share of assets held by the three largest banks in the Baltic countries and in other Central and Eastern European Countries (CEECs). Estonia and Lithuania stand out for the high degree of concentration in their banking sectors, as it is significantly higher than in Latvia or the other CEECs. The three largest banks in Lithuania had around $80 \%$ of total banking-sector assets in 2013, and in Estonia the three largest had more than 96\%. Most of the larger financial institutions in Estonia, Latvia, and Lithuania are Nordic banks. This high level of banking sector concentration in the Baltic countries is a result of privatisation and mergers following the banking crises in Estonia (1992-1994), Latvia (1995) and Lithuania (1995-1996). During this period, some banks were liquidated, while others were recapitalised, and the primary outcome was that the Baltic banking sector has become highly concentrated and largely foreign-owned because the governments encouraged bank mergers and foreign takeovers for fear of bank runs and credit contraction.

Since the empirical literature does not seem to provide a clear answer as to which view holds empirically, this paper addresses this well-worn debate for this group of countries. Understanding whether the high concentration levels in the banking sector in the Baltic countries affect the risk-taking behaviour of banks, and consequently the stability of the banking sector, is of key importance for regulation and competition policies.

This paper investigates empirically at bank level the relationship between competition and risk for a sample of forty commercial banks in the Baltic countries from 2000 to 2014. Rather than simply analysing the potential trade-off 
Figure 1: Concentration of banking sector assets: Baltic countries and other CEECs

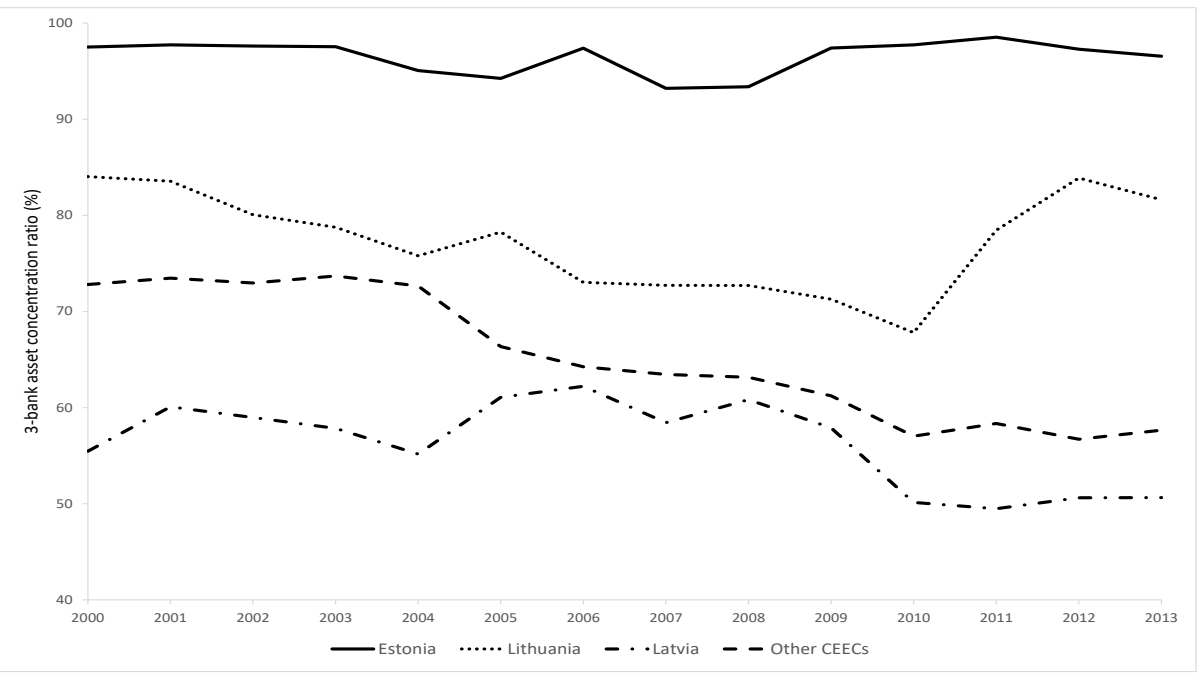

Source: Authors' calculations, Global Financial Development Database, The World Bank. Other CEECs: Albania, Bulgaria, Croatia, Czech Republic, Hungary, Poland, Romania, Slovak Republic, Slovenia.

between competition and financial stability in a linear fashion though, we follow the recent theoretical predictions from Martinez-Miera and Repullo (2010), and allow for the possibility of an inverse U-shaped relationship between competition and financial stability. The most recent literature on banking sector competition and concentration and financial stability highlights the importance of accounting for a U-shaped relationship between both measures. Doing so could let us identify an optimal degree of concentration and competition, and may indicate that both the competition-stability and the competition-fragility views are appropriate, depending on the level of concentration and competition ${ }^{1}$.

Martinez-Miera and Repullo (2010) establish that there may indeed be two separate effects in operation. One is the risk-shifting effect found by Boyd and De Nicoló (2005) where risk is reduced as competition increases, provided that there is a negative correlation between loan interest rates and competition, as this reduces the risk of loan defaults. The second effect is the margin effect, which implies that greater bank competition reduces interest payments, reducing the buffer against losses. According to Martinez-Miera and Repullo (2010) the riskshifting effect dominates in less competitive banking markets, so the marginal effect of a new bank entry is negative for financial stability, whereas in more competitive markets the margin effect overwhelms the risk-shifting effect, so a

\footnotetext{
${ }^{1}$ See, for instance, Berger et al. (2009), Fungáčová and Weill (2013), Jimenez et al. (2013), Liu et al. (2013), and Fu et al. (2014).
} 
new entry increases financial risk.

In the empirical literature, U-shaped relationships are usually tested by including a quadratic term in a standard regression model. If the estimated coefficient associated with this term is statistically significant and the estimated extremum point is within the data range, then it is common to conclude that there is a U-shaped relationship. In our paper, we go a step further and test the existence of a U-shaped relationship between bank competition and financial stability formally with the U-shape test developed by Lind and Mehlum (2010). This procedure also gives us a confidence interval for the optimal point. Such a confidence interval can be very useful for policy making, as it lets the regulatory authorities assess whether any financial institution has passed the upper bound, given the existence of a U-shaped relationship. It can be particularly useful for assessing whether the entry of new financial institutions or mergers could exacerbate financial instability.

We do this using balance-sheet data taken from the Bankscope database and we consider two types of bank risk proxy, the Z-score and the loan loss reserves. We also consider two different measures of competition, a structural measure derived from market share, and a non-structural measure from the Lerner index. As we will show in this paper, these two alternative measures of banking competition are not necessarily highly correlated, and they seem to capture different aspects of competition.

The remainder of the paper is organised as follows. Section 2 reviews the theoretical and empirical literature the on link between banking competition and financial (in)stability. Section 3 presents the data and the measures of competition and bank risk used. Section 4 presents the methodology and discusses the results. A battery of robustness checks is conducted in section 5, and section 6 concludes.

\section{Literature review}

This section summarises the literature on the issue analysed here of competition and concentration in the banking sector and financial stability. There is some controversy about whether measures of market concentration can be taken as proxies for market competition and vice versa. In this regard the empirical contributions seem to confirm that there is an inverse relationship between competition and concentration as concentration impairs competitiveness (see, e.g. Bikker and Haaf, 2002 or Gutiérrez de Rozas, 2007). However, as the next section details, this paper considers different proxies for the two measures.

As mentioned in the introduction, there are two main views on reconciling the relationship between competition and concentration and financial stability. The competition-stability hypothesis has its origins in the paper by Mishkin (1999), where it is hypothesised that a bank considering itself too big to fail would have increased incentives to take on riskier assets than otherwise as the government would in any case bail it out if it runs into trouble. This is the moral hazard 
problem. In this case, the government, or more accurately the taxpayer, bears the risk of the bank. In relation to this, Caminal and Matutes (2002) show that reduced competition can result in reduced credit rationing and larger loans, with a consequent increase in the probability of bank failures. In a seminal contribution Boyd and De Nicoló (2005) claim that a highly concentrated banking system allows banks to impose higher margins and hence higher borrowing rates for their clients. In this situation, corporate clients may be more inclined to engage in riskier projects seeking high and rapid returns, increasing the probability of failures.

On the other hand, the competition-fragility viewpoint states that more competitive or less concentrated banking systems may be more fragile. Marcus (1984) argues that the decline in franchise value caused by competition drives banks more towards risk-taking strategies because the opportunity cost of bankruptcy decreases. Furthermore, Boot and Greenbaum (1993) claim that banks extract less informational rent from borrowers in a more competitive environment, and this reduces their incentive to screen borrowers properly. In addition, Allen and Gale (2000) find that a concentrated banking market is more stable because it is easier for the supervisory authority to monitor banks. Finally, Boyd et al. (2006) point out that higher profits in highly concentrated banking systems may reduce financial fragility as they provide higher capital buffers.

Given the current policy relevance of the topic and the conflicting theoretical predictions, a number of empirical papers have investigated the relationship between banking sector competition and concentration and financial stability. However, the empirical findings do not all lead to the same conclusion. Indeed, while some cross-country analyses (see, for instance, Beck et al., 2006) argue that banking crises are less likely in economies with more concentrated banking systems, others show on the contrary that competitive banking sectors are less prone to systemic banking crises and exhibit increased time to crisis (see, for instance, Schaeck et al., 2009).The recent empirical investigation by Diallo (2015) seems to support the competition-fragility view, as it considers a large sample of emerging and industrial economies and uses different measures of bank competition and finds the opposite results to those of Schaeck et al. (2009). Diallo (2015) shows that bank competition increases the probability of a systemic banking crisis occurring and that it is also positively related to the duration of the crisis.

More recent evidence from studies with a European perspective also offers mixed results. The first paper to study the link between banking sector concentration and financial stability in Europe is that of Uhde and Heimeshoff (2009). They use an aggregate z-score as a measure of banking sector fragility for 25 European countries and show that banking market concentration that has a significant negative effect on financial stability. Their results suggest this negative relationship between concentration and stability may be explained by the higher volatility of the returns of larger banks in concentrated markets. In a recent paper, IJtsma et al. (2017) re-investigate this issue for the same sample of countries, but unlike Uhde and Heimeshoff (2009), they analyse them at both country level 
and bank level. Indeed, they show that if returns on assets of the banks are not perfectly correlated, the aggregated and bank-level z-scores measure different aspects of financial stability. Notably, the aggregate z-score accounts for systemic risk. In line with Uhde and Heimeshoff (2009), the results that they obtain suggest that concentration has a significant negative effect on stability. However, their findings also indicate that this effect is economically small at both levels of analysis. A similar result is obtained by Cifter (2015) for Central and Eastern European Countries (CEECs), as no robust relationship is found between bank concentration and non-performing loans.

Finally, a focus on empirical studies that investigate the competition-stability nexus using bank-level data also finds conflicting results ${ }^{2}$. For instance, results obtained by Agoraki et al. (2011) for a sample of CEECs suggest that a weak competitive environment is not necessarily synonymous with financial instability. Indeed, they find that banks with relatively high market power tend to take on lower credit risk and have a lower probability of default. The opposite is found by Schaeck and Čihák (2014), who show that competition in the banking sector enhances financial stability. They say that efficiency is the transmission mechanism through which competition contributes to stability. Using the Boone index as a proxy for banking sector competition and considering a large sample of European banks, Schaeck and Čihák (2014) find that competition is stabilityenhancing, but that this effect of competition on stability is greater for efficient banks than for inefficient ones.

However, Leroy and Lucotte (2017) show from a large sample of European listed banks that bank competition can have opposite effects on individual risk and systemic risk, which they proxy using the SRISK measure. Indeed, the results that they obtain suggest that competition encourages banks to take risks and then increases individual bank fragility, but tends to enhance financial stability by decreasing systemic risk. We also find two further studies for individual countries in the papers of Kick and Prieto (2015) and Jimenez et al. (2013), who analyse the relationship between competition and concentration and stability for the cases of Germany and Spain respectively. In the German case, the authors find evidence pointing towards the competition-fragility view, while for Spain nonlinear effects are found, which is in line with the theoretical predictions of Martinez-Miera and Repullo (2010).

Although most of the existing literature indicates that the competition-fragility hypothesis seems to hold empirically, we focus in our paper on the Baltic countries, which have not been studied much, and where concentration is among the highest in Europe. In addition, we also look at the potential nonlinear relationship between competition and bank risk.

\footnotetext{
${ }^{2}$ See Table A1 in the Appendix for an overview of bank-level analyses on the effect of bank competition on financial stability.
} 


\section{Data and stylised facts}

\subsection{Data, measures of competition, concentration and risk}

We consider all the commercial banks in the Baltic countries for which we have balance-sheet data over the period 2000-2014, giving an unbalanced panel data of 40 banks. Table 1 shows the list of banks, with their country and the period available. Our sample contains 21 banks in Latvia, 10 banks in Lithuania, and 9 banks in Estonia. All the data are taken from Bankscope, which is a database computed by Bureau Van Dijk.

Table 1: List of commercial banks located in the Baltic countries

\begin{tabular}{|c|c|c|c|c|c|}
\hline Bank Name & Country code & Period & Bank Name & Country code & Period \\
\hline Swedbank $\mathrm{AS}^{\text {sub }}$ & LV & $2001-2014$ & Swedbank $\mathrm{AS}^{\text {sub }}$ & $\mathrm{EE}$ & $2000-2014$ \\
\hline ABLV Bank AS ${ }^{c o r}$ & LV & $2002-2014$ & SEB Pank ${ }^{\text {sub }}$ & $\mathrm{EE}$ & $2000-2014$ \\
\hline SEB banka $\mathrm{AS}^{\text {sub }}$ & LV & $2000-2014$ & Danske Bank A/S Estonia Branch bra & $\mathrm{EE}$ & $2000-2007$ \\
\hline Rietumu Bank Group-Rietumu Banka ${ }^{\text {cor }}$ & LV & $2000-2014$ & DNB Pank $\mathrm{AS}^{\sin }$ & $\mathrm{EE}$ & $2011-2014$ \\
\hline AS Citadele Banka ${ }^{\text {sub }}$ & LV & $2010-2014$ & AS LHV Pank & $\mathrm{EE}$ & $2012-2014$ \\
\hline AS DnB Banka & LV & $2004-2014$ & BIGBANK $\mathrm{AS}^{\mathrm{cor}}$ & $\mathrm{EE}$ & $2006-2014$ \\
\hline Norvik Banka $\mathrm{AS}^{\text {sub }}$ & LV & $2006-2014$ & Estonian Credit Bank-Eesti Krediiidipank ${ }^{\text {sub }}$ & $\mathrm{EE}$ & $2000-2014$ \\
\hline Latvijas Kraj Banka AS-Latvian Savings Bank $k^{s u b}$ & LV & $2005-2010$ & Versobank $\mathrm{AS}^{\text {sub }}$ & $\mathrm{EE}$ & $2011-2014$ \\
\hline As PrivatBank ${ }^{\text {sub }}$ & LV & 2004-2014 & Tallinn Business Bank Ltd-Tallinna Åripanga AS ${ }^{c o r}$ & $\mathrm{EE}$ & $2010-2013$ \\
\hline Baltikum Bank $A S^{s u b}$ & LV & $2005-2014$ & AB SEB Bankas sub & LT & $2000-2014$ \\
\hline Regionala investiciju banka-Regional Investment Bank ${ }^{\text {sub }}$ & LV & $2003-2014$ & Swedbank $\mathrm{AB}^{\text {sub }}$ & LT & $2003-2014$ \\
\hline Trasta Komercbanka-Trust Commercial Bank ${ }^{c o r}$ & LV & $2000-2014$ & AB DNB Bankas ${ }^{\text {sub }}$ & LT & $2000-2014$ \\
\hline Baltic International Bank- Baltijas Starptautiska Banka sub & LV & 2009-2014 & AB Bankas Snoras ide & LT & $2000-2010$ \\
\hline AS Expobank ${ }^{b r a}$ & LV & $2012-2014$ & Danske Bank A/S Sra $^{\text {bra }}$ & LT & $2000-2014$ \\
\hline Danske Bank A/S sub & LV & $2000-2007$ & Siauliu Bankas ${ }^{\text {cor }}$ & LT & $2000-2014$ \\
\hline Jsc Latvian Development Financial Institution Altum ${ }^{\text {sin }}$ & LV & $2003-2013$ & Citadele Bankas $\mathrm{AB}^{\text {sub }}$ & LT & $2006-2014$ \\
\hline Meridian Trade Bank AS ${ }^{\text {ind }}$ & LV & 2003-2014 & UAB Medicinos Bankas sub & LT & $2000-2014$ \\
\hline AS Reverta ${ }^{\text {sub }}$ & LV & $2000-2014$ & AB Bankas FINASTA $^{\text {sub }}$ & LT & $2009-2014$ \\
\hline Bank M2M Europe $\mathrm{AS}^{\text {sub }}$ & LV & $2005-2009,2013-2014$ & Skandinaviska Enskilda Banken AB; Vilniaus Filialia ${ }^{\text {sin }}$ & LT & $2009-2014$ \\
\hline JSC Latvijas Pasta banka ${ }^{\text {sub }}$ & LV & $2009-2014$ & & & \\
\hline GE Capital Latvia ${ }^{\text {sub }}$ & LV & 2004-2012 & & & \\
\hline
\end{tabular}

Source: Bankscope. Type of Bank entity: sub - controlled subsidiary, cor - corporate group, bra branch, sin - single location, ind - independent, ide - not identified

Since our analysis aims to investigate the relationship between banking competition and risk-taking by banks, we first need to choose a bank-level measure of competition. As Northcott (2004) argued however, there is no consensus in the literature about the best indicator for gauging competition. The literature traditionally distinguishes two types of measure of competition, these being structural and non-structural measures. Structural measures come within the Structure-Conduct-Performance (SCP) paradigm, which was initially developed by Mason (1939) and Bain (1959), and they are based on the assumption that the competitive behaviour of banks is principally determined by the structural characteristics of the market in which they operate, such as the degree of market concentration. In this paradigm, a concentrated market structure is associated with higher prices and profits, reflecting uncompetitive behaviour by firms. This paradigm has been criticised however, because higher profits in the banking sector could also be the result of greater production and managerial efficiency, as shown for example by Smirlock (1985), Evanoff and Fortier (1988), and Berger (1995) for the US banking sector. 
Criticisms of the SCP paradigm have led a number of recent studies to prefer non-structural competition measures for analysing the competitive features of the banking industry. These measures lie within the New Empirical Industrial Organisation framework and compare some form of price mark-up against a competitive benchmark, with a higher mark-up reflecting greater market power and a less competitive environment. A variety of non-structural measures of competition have been developed in the academic literature. The two best-known of them are probably the Lerner index (Lerner, 1934) and the H-statistic developed by Panzar and Rosse (1987). More recently, Boone (2008) extended the existing set of non-structural competition measures by proposing a macro-level index of competition. This index draws on the idea that more efficient firms achieve superior performance in higher profits or larger market shares, and that this effect is stronger the heavier the competition is. The main advantage of non-structural measures of competition over structural indicators is that they are micro-founded and therefore offer a more realistic setting for estimating competitive conditions in the banking sector.

A number of studies compare the structural and non-structural measures of competition for the banking sector and investigate their relationships empirically. One of the first studies on this issue was conducted by Bikker and Haaf (2002). They consider a large sample of banks from twenty-three European and non-European countries and compute the H-statistic and regress it on different measures of banking sector concentration, such as the Herfindahl-Hirschman Index (HHI). Their results are in line with the SCP paradigm and provide evidence that concentration impairs competitiveness. Extending the sample of countries however, Claessens and Laeven (2004) find opposite results, and do not find the expected negative relationship between banking sector concentration and the H-statistic. On the contrary, they find a positive and statistically significant relationship, suggesting that banks operating in more concentrated sectors face a greater degree of competition. In a similar way, Carbó et al. (2009) assess the relative competitive position of banking markets in fourteen European countries by focusing on different structural and non-structural measures of competition. Like Bikker and Haaf (2002), they do not find a high correlation between the Lerner index and the HHI structural measure. More generally, they show that the existing indicators of competition give conflicting predictions across countries, within countries, and over time, even if they seem to provide similar rankings. Similar results are obtained by Lapteacru (2014) for the Central and Eastern European Countries (CEECs), finding relatively low pair-wise correlations between the three measures of competition considered, the HHI, the Lerner index, and the H-statistic. As argued by Carbó et al. (2009), a cause of the divergence between competition indicators could be that they tend to measure different aspects and are additionally influenced by cross-country differences in cost efficiency, fee income levels, real economic growth and inflation. This divergence may also explain why the majority of empirical studies in the banking literature often use only one measure of competition, structural or non-structural.

Against this background, and given the large debate in the literature con- 
cerning the reliability of these measures of competition, we adopt a conservative approach and choose to use both a structural measure of bank-level competition and a non-structural one. The structural measure we consider is market share, and the non-structural measure is the Lerner index. The market share corresponds to the amount of assets held by each bank divided by the total assets of the national banking sector. This ratio of between 0 and $100 \%$ is positively related to the degree of market concentration, so in the SCP paradigm it is an inverse proxy for bank competition, meaning that a low value indicates a high degree of competition and vice versa.

The Lerner index is also an inverse proxy for competition. It is designed to measure the pricing power of firms and corresponds to the mark-up of price over marginal cost. The Lerner index is bounded between 0 and 1, with the extreme value of zero corresponding to perfect competition, and the value of one to a pure monopoly. As stated by Leroy and Lucotte (2017), the main advantage of the Lerner index is that it is the only time-varying non-structural measure of competition that can be computed at the disaggregated level of the firm. This certainly explains why the Lerner index has been used as a proxy for firm-level competition by a number of recent empirical studies in the banking literature (see table A1 in the Appendix).

Formally, the Lerner index corresponds to the difference between price and marginal cost as a percentage of price. It can be written as follows:

$$
\text { Lerner }_{i t}=\frac{p_{i t}-m c_{i t}}{p_{i t}}
$$

with $p_{i t}$ the price and $m c_{i t}$ the marginal cost for the bank $i$ in period $t$. Under the assumption that the heterogeneous flow of services produced by a bank is proportional to its total assets, the price $p_{i t}$ is calculated as the ratio of total revenue (the sum of interest and non-interest income) to total assets.

To obtain the marginal cost, we adopt an approach that is conventional in the literature (see, e.g., Berger et al., 2009 or Beck et al., 2013) and model the total operating cost of running the bank as a function of a single, aggregate output proxy, $Q_{i t}$, and three input prices, $W_{1, i t}, W_{2, i t}$, and $W_{3, i t}$. More precisely, we estimate the following translog cost function:

$$
\begin{aligned}
& \ln C_{i t}=\beta_{0}+\beta_{1} \ln Q_{i t}+\frac{\beta_{2}}{2} \ln Q_{i t}^{2}+\sum_{k=1}^{3} \gamma_{k} \ln W_{k, i t}+\sum_{k=1}^{3} \phi_{k} \ln Q_{i t} \ln W_{k, i t} \\
& +\sum_{k=1}^{3} \sum_{j=1}^{3} \frac{\rho_{k j}}{2} \ln W_{k, i t} \ln W_{j, i t}+\delta_{1} T+\frac{\delta_{2}}{2} T^{2}+\delta_{3} T \ln Q_{i t}+\sum_{k=4}^{6} \delta_{k} T \ln W_{k, i t}+\varepsilon_{i t}
\end{aligned}
$$

in which $C_{i t}$ measures the total operating costs from interest expenses, personnel costs, and other administrative and operating costs for bank $i$ at the period $t$, and $Q_{i t}$ represents a proxy for bank output and corresponds to the total assets. $W_{1, i t}$, $W_{2, i t}$ and $W_{3, i t}$ are the prices of inputs. $W_{1, i t}$ is the ratio of interest expenses to total assets, $W_{2, i t}$ is the ratio of personnel expenses to total assets, and $W_{3, i t}$ is the 
ratio of administrative and other operating expenses to total assets. $T$ is a trend that is included to capture technical changes and potential movements in the cost function over time. Furthermore, to reduce the influence of outliers, all variables are winsorised at the 1st and 99th percentile levels (see, e.g., Berger et al., 2009 or Anginer et al., 2014). Following Turk-Ariss (2010) and Liu et al. (2013), we also scale cost and input prices by $W_{3}$ to correct for heteroscedasticity and scale biases. We further impose the following restrictions on regression coefficients to ensure homogeneity of degree one in input prices: $\sum_{k=1}^{3} \gamma_{k, t}=1, \sum_{k=1}^{3} \phi_{k}=0$ and $\sum_{k=1}^{3} \sum_{j=1}^{3} \rho_{k}=0$.

Because there are a relatively low number of observations, the equation (2) is not estimated separately for each Baltic country. We estimate the translog cost function on the whole sample of commercial banks in the Baltic countries, and we include country fixed effects in the regression to control for potential differences in technology across economies. The coefficient estimates from equation (2) are then used to calculate the marginal cost for each bank $i$ at each period $t$ :

$$
m c_{i t}=\frac{\partial C_{i t}}{\partial Q_{i t}}=\frac{C_{i t}}{Q_{i t}}\left(\hat{\beta}_{1}+\hat{\beta}_{2} \ln Q_{i t}+\sum_{k=1}^{3} \hat{\theta_{k}} \ln W_{k, i t}+\hat{\delta_{3}} T\right)
$$

However, as argued by Turk-Ariss (2010), one important problem associated with the estimation of the conventional Lerner index is that it implicitly assumes full bank efficiency and does not consider the possibility that banks may not exploit the pricing opportunities that result from market power. Indeed, banks with a large amount of market power could choose the quiet life and reduce their cost efficiency (Hicks, 1935 or Berger and Hannan, 1998) ${ }^{3}$. Alternatively, efficiency could also lead to the market being concentrated in the hands of the most efficient banks (Demsetz, 1973; Peltzman, 1977). Consequently, as shown by Koetter et al. (2012), not controlling for inefficiency is problematic because it can affect the difference between price and marginal cost, and this then biases the estimation of the Lerner index.

We account for this bias by not proxying the market power of banks using the conventional Lerner index, but instead by considering the efficiency-adjusted Lerner index proposed by Koetter et al. (2012), defined as:

$$
\text { AdjustedLerner }_{i t}=\frac{\left(\hat{\pi}_{i t}+\hat{C}_{i t}\right)-\hat{m} c_{i t}}{\left(\hat{\pi}_{i t}+\hat{C}_{i t}\right)}
$$

where $\hat{\pi}_{i t}$ is the estimated profit, $\hat{C}_{i t}$ the estimated total cost, and $\hat{m} c_{i t}$ the estimated marginal cost.

To calculate this adjusted Lerner index, we follow Koetter et al. (2012) and first estimate the translog cost function (equation 2) using a Stochastic Frontier Analysis (SFA). We then obtain $\hat{C}_{i t}$ and $\hat{m} c_{i t}$. This an approach has the advantage of taking into account banks' cost inefficiency, defined as the distance of

\footnotetext{
${ }^{3}$ Note nonetheless that empirical results obtained by Maudos and de Guevara (2007) for a large sample of European banks do not confirm the quiet life hypothesis. On the contrary, they find a positive relationship between market power and the cost X-efficiency.
} 
a bank from a cost frontier accepted as the benchmark. Second, we specify an alternative profit function (Berger and Hannan, 1998), that we estimate using a SFA to obtain $\hat{\pi}_{i t}$.

Finally, we consider two alternative proxies for measures of bank risk: the Z-score and the loan loss reserves as a percentage of gross loans. The loan loss reserves are a measure of credit risk, while the Z-score is a commonly-used accounting-based measure of bank stability. The Z-score explicitly compares the buffers of capitalisation and returns with risk from the volatility of returns to measure how far a bank is from insolvency. It is defined as:

$$
Z_{\text {score }} i t=\frac{E_{i t} / A_{i t}+\mu_{R O A_{i t}}}{\sigma_{R O A_{i t}}}
$$

where $\mu_{R O A_{i t}}$ is the expected return on assets, $E_{i t} / A_{i t}$ is the equity to total assets ratio, and $\sigma_{R O A_{i t}}$ is the standard deviation of the return on assets.

The Z-score is inversely related to the probability of a bank becoming insolvent. A higher Z-score implies a lower probability of this happening. Because a bank becomes insolvent when the value of its assets drops below that of its debt, the Z-score can be interpreted as the number of standard deviations that a bank's return must fall below its expected value by to wipe out all the equity in the bank and render it insolvent (Boyd and Runkle, 1993). This study opts for the approach used by Beck et al. (2013) to compute the standard deviation of $\mathrm{ROA}^{4}$. This approach uses a three-year rolling time window to compute the standard deviation of ROA rather than the full sample period, whereas the return on assets and the equity to total assets ratio are contemporaneous. As argued by Beck et al. (2013), this approach has two main advantages. First, it avoids the variation in the Z-score within banks that is exclusively driven over time by variation in the levels of capital and profitability. Second, given the unbalanced nature of our panel dataset, it avoids the denominator being computed at different window lengths for different banks.

\subsection{Stylised facts}

Before turning to the econometric analysis, we present the main cross-sectional and times series features of the Lerner index and the market share variable, and analyse whether they are linked to our proxies for bank risk. Table 2 reports the mean of the Lerner index and the bank market share for the Baltic countries for different sub-periods and for the overall period. We can observe in all the Baltic countries that the market power of commercial banks seems to have decreased between 2000 and 2014. This evolution is the most pronounced for Latvia, where the average of the Lerner index went from 0.72 in $2000-04$ to 0.33 in 2010-14, and the average market share went from $13.73 \%$ in $2000-04$ to $5.63 \%$ in $2010-14$. We find that, in any case, Estonia is the Baltic country with the highest values

\footnotetext{
${ }^{4}$ See Lepetit and Strobel (2013) for a review of different methodologies for computing the Z-score.
} 
for the Lerner index and the bank market share, which is consistent with the findings reported in figure 1.

Table 2: Evolution of the Lerner index and the market share in Baltic countries

\begin{tabular}{lcccccc}
\hline & \multicolumn{3}{c}{ Lerner index $(\mathrm{mean})$} & \multicolumn{4}{c}{ Market share in\% (mean) } \\
\hline Sub-periods & Estonia & Lithuania & Latvia & Estonia & Lithuania & Latvia \\
$2000-2004$ & 0.652 & 0.512 & 0.716 & 25.00 & 15.718 & 13.73 \\
$2005-2009$ & 0.608 & 0.428 & 0.532 & 22.95 & 12.358 & 5.964 \\
$2010-2014$ & 0.562 & 0.35 & 0.334 & 14.268 & 10.888 & 5.628 \\
\hline Overall period & & & & & & \\
$2000-2014$ & 0.6 & 0.41 & 0.48 & 19.26 & 12.61 & 7.01 \\
\hline \hline
\end{tabular}

Source: Authors' calculation based on the Bankscope database. Note: The Lerner index refers to the adjusted Lerner index proposed by Koetter et al. (2012)

In table 3 we report the value of the Lerner index and of the market share in 2014 for all the commercial banks considered in our sample. For the market share, we can see that the distribution of activity across banks is relatively more homogeneous in Latvia than in Lithuania and Estonia. Indeed two banks in Lithuania, AB SEB Bankas and Swedbank AB, have a market share of more than $30 \%$, while in Latvia Swedbank AS had the largest market share at $18.75 \%$ in 2014. More importantly, fewer than one quarter of the banks in Latvia had a market share of more than 10\%. In Estonia, the banking industry is dominated by two foreign banks, SEB Pank and Swedbank AS, which between them hold nearly $85 \%$ of the banking sector assets. Furthermore, these two banks are also notable for the high values they recorded for the Lerner index in 2014 at 0.90 or more, which would indicate that our two proxies for market power give similar patterns. However, the picture for small banks is less clear, since four of them, AS LHV Pank, DNB Pank AS, Tallinn Business Bank Ltd and Versobank AS, had a Lerner index above 0.60 in 2014.

The low correlation between our two proxies for market power in Estonia is confirmed by figure 2. In contrast to the results for Latvia and Lithuania, the Estonian data suggest a non-significant correlation between market share and the Lerner index for the Estonian banking sector. This reinforces our decision to consider two alternative measures of bank market power.

Finally, in figure 3 we plot the Lerner index (x-axis) against the Z-score and the loan loss reserves (y-axis), while in figure 4 we plot market share ( $\mathrm{x}$ axis) against our alternative measures of bank risk-taking. In each case, we consider both linear and nonlinear fitted values. The R-squared are obtained by regressing each measure of risk on the Lerner index or the market share, and by considering a linear or a quadratic function. The result shows that a relatively tight relationship exists between the Lerner index and the risk measures, while the link is less clear when we consider the market share of the banks. This 
relationship is negative with loan loss reserves, and positive with the Z-score, which is an inverse proxy for bank-individual risk. This preliminary result is in line with the competition-fragility view. More importantly, bottom scatter plots reported in figure 3 indicate a potential nonlinear relationship between the Lerner index and the Z-score, and between the Lerner index and the loan loss reserves. The next section provides an in-depth assessment of this issue.

Table 3: Lerner index and market share of commercial banks located in Baltic countries in 2014

\begin{tabular}{|c|c|c|c|c|c|c|c|c|}
\hline & \multicolumn{2}{|c|}{ Latvia } & \multicolumn{4}{|c|}{ Lithuania } & \multicolumn{2}{|c|}{ Estonia } \\
\hline & Lerner index & Market share & & Lerner index & Market share & & Lerner index & Market share \\
\hline ABLV Bank AS & 0.76 & 15.78 & AB Bankas FINAST & 0.05 & 0.30 & AS LHV Pank & 0.61 & 3.13 \\
\hline AS Citadele Banka & 0.66 & 10.55 & AB Bankas Snoras & n.a. & n.a. & BIGBANK AS & 0.21 & 1.88 \\
\hline AS DNB Banka & 0.64 & 8.73 & AB DNB Bankas & 0.42 & 17.97 & DNB Pank AS & 0.68 & 3.75 \\
\hline AS Expobank & 0.61 & 1.81 & AB SEB Bankas & 0.73 & 32.21 & Danske Bank A/S & n.a. & n.a. \\
\hline AS Reverta & -0.04 & 0.85 & Citadele Bankas AB & 0.01 & 2.04 & Estonian Credit Bank & 0.31 & 1.48 \\
\hline Baltic International Bank & 0.03 & 1.96 & Danske Bank A/S & 0.66 & 8.44 & SEB Pank & 0.90 & 30.03 \\
\hline Baltikums Bank AS & 0.57 & 2.31 & Siauliu Bankas & 0.45 & 7.83 & Swedbank As & 0.91 & 54.00 \\
\hline Bank M2M Europe AS & 0.31 & 0.57 & Skandinaviska Enskilda Banken AB & 0.09 & 0.01 & Tallinn Business Bank Ltd & $0.60^{*}$ & $1.12^{*}$ \\
\hline Danske Bank A/S & n.a. & n.a. & Swedbank AB & 0.71 & 30.02 & Versobank AS & 0.65 & 1.48 \\
\hline GE Capital Latvia & $0.01^{* *}$ & $0.46^{* *}$ & UAB Medicinos Bankas & -0.01 & 1.17 & & & \\
\hline JSC Latvijas Pasa Banka & 0.27 & 0.52 & & & & & & \\
\hline Jsc Latvian Dev. Fin. Inst. Altum & $-0.01^{*}$ & $1.17^{*}$ & & & & & & \\
\hline Latvijas Krajbanka & n.a. & n.a. & & & & & & \\
\hline Meridian Trade Bank AS & 0.02 & 0.93 & & & & & & \\
\hline Norvik Banka AS & 0.02 & 4.28 & & & & & & \\
\hline PrivatBank & 0.54 & 2.51 & & & & & & \\
\hline Regionala Investiciju Banka & 0.02 & 2.19 & & & & & & \\
\hline Rietumu Bank Group & 0.73 & 12.86 & & & & & & \\
\hline SEB Banka AS & 0.72 & 13.29 & & & & & & \\
\hline Swedbank AS & 0.76 & 18.75 & & & & & & \\
\hline Trasta Komercbanka & 0.01 & 2.12 & & & & & & \\
\hline
\end{tabular}

Source: Authors' calculation based on the Bankscope database. Note: The Lerner index refers to the adjusted Lerner index proposed by Koetter et al. (2012). Due to data availability, * refers to the Lerner index and the market share in 2013, and ** to the Lerner index and the market share in 2012. N.A. means that balance sheet data are not available for those years.

\section{Methodology and results}

Following the theoretical results from Martinez-Miera and Repullo (2010), we examine whether nonlinear causality exists between the proxies for concentration and competition and our alternative measures of risk. To this end, we include the squared term of the Lerner index or of the market share. Such a nonlinear investigation is useful from a policy point of view, as it allows an optimal threshold to be identified beyond which bank competition, or inversely a lack of competition, becomes dangerous for the stability of the banking sector. Our analysis is based upon the following regression:

$$
\text { risk }_{i t}=\alpha+\beta_{1} \text { Comp }_{i t-1}+\beta_{2} \operatorname{Comp}_{i t-1}^{2}+\beta_{3} \text { Crisis }_{t}+\sum_{k=4}^{n} \beta_{k} X_{i t-1}+\mu_{i}+\gamma_{t}+\varepsilon_{i t}
$$

where $i$ and $t$ are respectively the bank and time period indicators, $r i s k_{i t}$ represents one or another of our of our measures of risk, Comp $p_{i t-1}$ represents one or another of our measures of market power, either the Lerner index or the bank market share, Crisis $s_{t}$ is a dummy variable capturing the subprime crisis episode, 
Figure 2: Correlation between the market share and the Lerner index
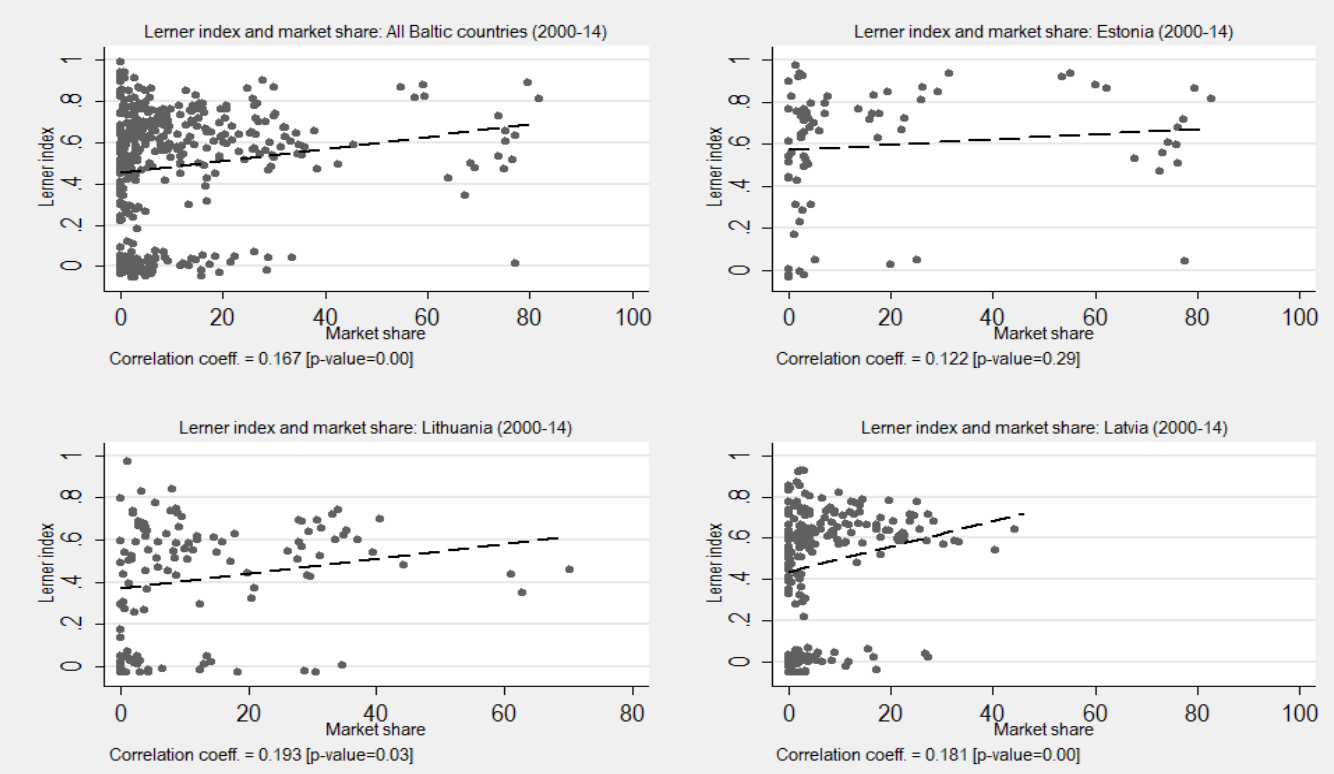

Note: The Lerner index refers to the adjusted Lerner index proposed by Koetter et al. (2012).

equal to 1 from 2008 to 2012 and zero otherwise, and $X_{i t-1}$ is the vector of control variables. The term $\mu_{i}$ is an individual specific effect, $\gamma_{t}$ is an unobserved time effect included to capture common time-varying factors, and $\varepsilon_{i t}$ is the random error term. This specification is similar in many ways to that considered by recent studies that have investigated the competition-stability trade-off (see, for instance, Leroy and Lucotte, 2017). Equation (6) is estimated using the fixed effects (FE) estimator.

However, examining whether market power influences risk-taking by banks raises the question of endogeneity bias. Indeed, Schaeck and Čihák (2008) argued that the level of risk-taking could affect the competitiveness of banks, which could then impact our measures of market power. Banks might have an incentive to gamble in the hope of resurrection when they face a high probability of default. They may even be more inclined to change the price of their products so as to access new financial resources and attract new customers, thus affecting the existing market power. To address this potential endogeneity issue, we lag our proxies for market power by one period and do the same for all the control variables. We further consider an instrumental variable approach using the twostage least squares (2SLS) estimator. We consider three instrumental variables, which are the first lag of the market power proxy considered, and two variables proxying cost inefficiency, these being the ratio of overhead expenses to total assets and the cost-to-income ratio.

The results obtained are reported in tables 4 and 5 when we consider the Lerner index as right-hand side variable, and in tables 6 and 7 when we con- 
Figure 3: Scatterplots between the Lerner index and alternative measures of risk
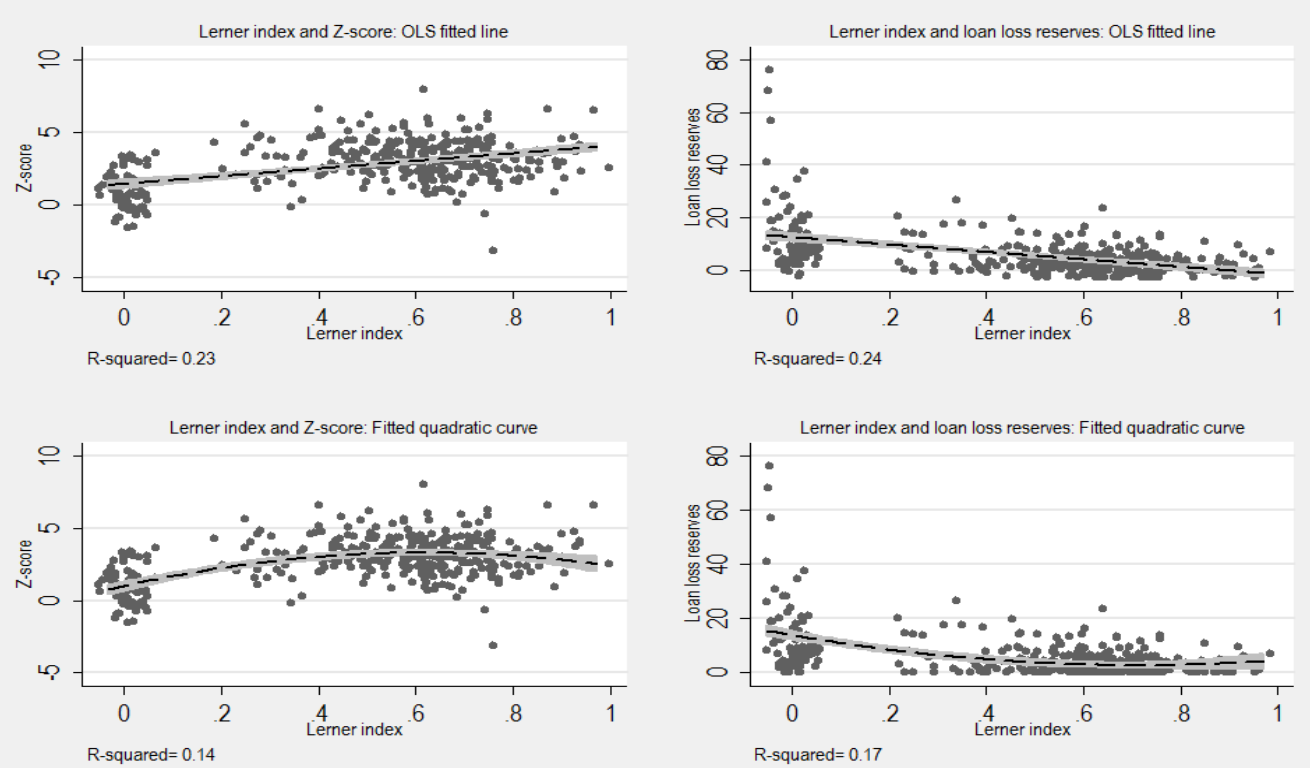

Note: The shaded area represents the $95 \%$ confidence interval. The Lerner index refers to the adjusted Lerner index proposed by Koetter et al. (2012).

sider the market share as a proxy for competition. For each specification, we report the turning point, representing the optimal threshold, when the U-shape test developed by Lind and Mehlum (2010) indicates a statistically significant nonlinear relationship between our proxies for bank market power and our alternative measures of risk. In this case, we also report the confidence interval for the extreme point, using the Fieller $\operatorname{method}^{5}$.

Table 4 reveals that the results for each specification show an inverse Ushaped relationship between the Lerner index and the Z-score. The turning points vary between 0.57 and 0.64 , suggesting that market power tends to increase the fragility of the banking sector beyond this threshold. The results that we obtain between the Lerner index and loan loss reserves are more mixed. Indeed, the results reported in table 5 only indicate a U-shaped relationship between these two variables when we estimate equation (6) using a 2SLS estimator. In this case, the turning points vary between 0.66 and 0.70 .

We do not find a significant nonlinear relationship between the market share and the Z-score (see table 6). More interestingly, the results reported in table 7 suggest a U-shaped relationship between the market share of the bank and its loan loss reserves. For each specification, the coefficient estimates associated with the market share and the interaction term appear statistically significant at the conventional levels. The turning points vary between $44 \%$ and $52 \%$.

Consequently, our nonlinear analysis suggests that a low degree of bank com-

\footnotetext{
${ }^{5}$ See Lind and Mehlum (2010) for more details concerning the U-shape test and the computation of the confidence interval.
} 
Figure 4: Scatterplots between market share and alternative measures of risk
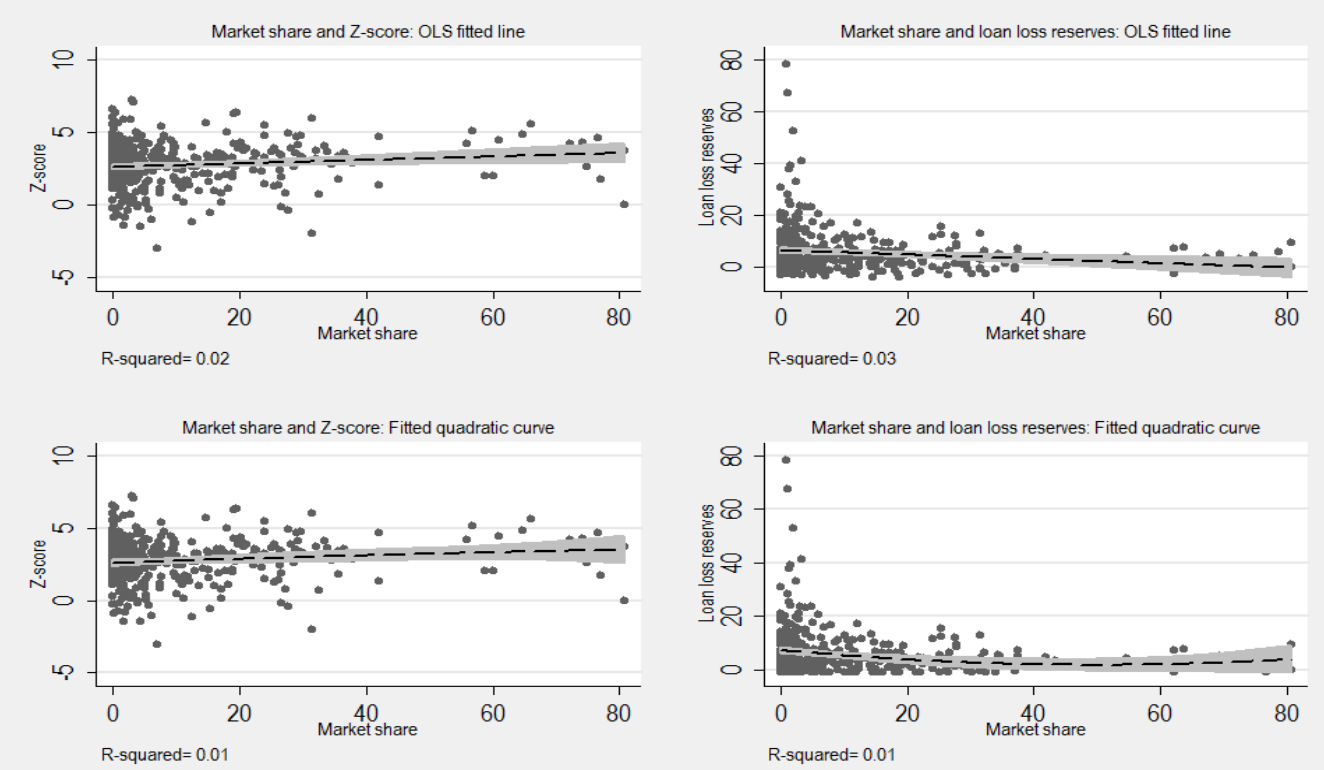

Note: The shaded area represents the $95 \%$ confidence interval.

petition is likely to exacerbate risk-taking by banks and then be detrimental to the stability of the banking sector in the Baltic countries. In line with the theoretical predictions of Martinez-Miera and Repullo (2010), we find a very stable and statistically significant inverse U-shaped relationship between the Lerner index and the Z-score, a measure of solvency risk. This means that banking sector fragility is higher in either very competitive or very monopolistic markets, and lowest when there are moderate levels of competition.

If we now compare each commercial bank in the Baltic countries in 2014 with the average optimal thresholds for the Lerner index and the market share, we can see from figure A6 that only one financial institution, Swedbank AS in Estonia, lies above both threshold values. The situation is more mixed for Lithuania and Latvia, as a number of banks in Latvia exhibit a Lerner index that is higher than the optimal threshold but have market shares of between $10 \%$ and $20 \%$, which appears relatively low next to the shares seen in Estonia and Lithuania ${ }^{6}$.

\footnotetext{
${ }^{6} \mathrm{~A}$ graphical representation of the marginal effects is displayed in figure A5 of the Appendix.
} 
Table 4: Market power and bank risk-taking: The nonlinear relationship between the Lerner index and the Z-score

\begin{tabular}{|c|c|c|c|c|c|c|}
\hline & $(1)$ & $(2)$ & $(3)$ & $(4)$ & $(5)$ & $(6)$ \\
\hline Dependent variable & $\begin{array}{c}\text { Z-score } \\
\text { FE }\end{array}$ & $\begin{array}{l}\text { Z-score } \\
\text { FE }\end{array}$ & $\begin{array}{c}\text { Z-score } \\
\text { FE }\end{array}$ & $\begin{array}{c}\text { Z-score } \\
\text { 2SLS }\end{array}$ & $\begin{array}{c}\text { Z-score } \\
\text { 2SLS }\end{array}$ & $\begin{array}{l}\text { Z-score } \\
\text { 2SLS }\end{array}$ \\
\hline Lerner & $\begin{array}{c}5.014^{* * *} \\
(1.102)\end{array}$ & $\begin{array}{c}5.031^{* * *} \\
(1.135)\end{array}$ & $\begin{array}{c}5.056^{* * *} \\
(1.212)\end{array}$ & $\begin{array}{c}13.924^{* * *} \\
(3.490)\end{array}$ & $\begin{array}{c}14.067^{* * *} \\
(3.523)\end{array}$ & $\begin{array}{c}14.922^{* * *} \\
(3.310)\end{array}$ \\
\hline Lerner*Lerner & $\begin{array}{c}-4.306^{* * *} \\
(1.258)\end{array}$ & $\begin{array}{c}-4.368^{* * *} \\
(1.327)\end{array}$ & $\begin{array}{c}-4.344^{* * *} \\
(1.439)\end{array}$ & $\begin{array}{c}-10.916^{* * *} \\
(3.140)\end{array}$ & $\begin{array}{c}-10.906^{* * *} \\
(3.218)\end{array}$ & $\begin{array}{c}-12.088^{* * *} \\
(3.182)\end{array}$ \\
\hline Inflation & & $\begin{array}{c}0.033 \\
(0.065)\end{array}$ & $\begin{array}{c}0.006 \\
(0.063)\end{array}$ & & $\begin{array}{l}-0.027 \\
(0.077)\end{array}$ & $\begin{array}{l}-0.059 \\
(0.080)\end{array}$ \\
\hline GDP growth & & $\begin{array}{l}-0.027 \\
(0.049)\end{array}$ & $\begin{array}{l}-0.025 \\
(0.050)\end{array}$ & & $\begin{array}{l}-0.038 \\
(0.056)\end{array}$ & $\begin{array}{l}-0.021 \\
(0.055)\end{array}$ \\
\hline Crisis dummy & $\begin{array}{c}-2.743^{* * *} \\
(0.438)\end{array}$ & $\begin{array}{c}-1.263^{* *} \\
(0.551)\end{array}$ & $\begin{array}{l}-1.367 \\
(0.858)\end{array}$ & $\begin{array}{c}-1.621^{* * *} \\
(0.462)\end{array}$ & $\begin{array}{c}-1.397^{* *} \\
(0.597)\end{array}$ & $\begin{array}{c}-1.529 * * * \\
(0.529)\end{array}$ \\
\hline 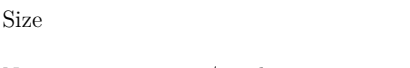 & & & $\begin{array}{l}0.023 \\
(0.132)\end{array}$ & & & $\begin{array}{l}-0.171 \\
(0.215)\end{array}$ \\
\hline Non-interest income/total income & & & $\begin{array}{l}-0.577 \\
(0.600)\end{array}$ & & & $\begin{array}{l}-0.566 \\
(0.919)\end{array}$ \\
\hline Fixed assets/total assets & & & $\begin{array}{c}4.767 \\
(8.028)\end{array}$ & & & $\begin{array}{c}3.974 \\
(6.083)\end{array}$ \\
\hline Loans/total assets & & & $\begin{array}{c}2.122 \\
(1.464)\end{array}$ & & & $\begin{array}{c}2.672 \\
(1.723)\end{array}$ \\
\hline Liquidity & & & $\begin{array}{l}0.005 \\
(0.011)\end{array}$ & & & $\begin{array}{c}0.007 \\
(0.011) \\
\end{array}$ \\
\hline U-shape test & $\begin{array}{c}2.30 \\
{[0.013]}\end{array}$ & $\begin{array}{c}2.21 \\
{[0.016]}\end{array}$ & $\begin{array}{c}2.00 \\
{[0.026]}\end{array}$ & $\begin{array}{c}2.44 \\
{[0.007]}\end{array}$ & $\begin{array}{c}2.27 \\
{[0.011]}\end{array}$ & $\begin{array}{c}2.69 \\
{[0.003]}\end{array}$ \\
\hline $\begin{array}{l}\text { Turning point } \\
95 \% \text { confidence interval, Fieller method }\end{array}$ & $\begin{array}{c}0.582 \\
{[0.485 ; 0.862]}\end{array}$ & $\begin{array}{c}0.576 \\
{[0.474 ; 0.889]}\end{array}$ & $\begin{array}{c}0.582 \\
{[0.478 ; 0.983]}\end{array}$ & $\begin{array}{c}0.638 \\
{[0.540 ; 0.838]}\end{array}$ & $\begin{array}{c}0.645 \\
{[0.541 ; 0.877]}\end{array}$ & $\begin{array}{c}0.617 \\
{[0.533 ; 0.789]}\end{array}$ \\
\hline Year fixed effects & Yes & Yes & Yes & Yes & Yes & Yes \\
\hline Observations & 350 & 350 & 346 & 343 & 343 & 339 \\
\hline R-squared & 0.430 & 0.431 & 0.447 & 0.187 & 0.171 & 0.188 \\
\hline Number of banks & 40 & 40 & 39 & 40 & 40 & 39 \\
\hline Hansen J-OverID test [p-value] & - & - & - & 0.0980 & 0.130 & 0.162 \\
\hline
\end{tabular}

Note: Constant included but not reported. Robust standard errors clustered at bank level are reported below their coefficient estimates. The Hansen test evaluates the joint validity of instruments used. *, ** and *** indicate statistical significance at the $10 \%, 5 \%$ and $1 \%$ levels, respectively. The Lerner index refers to the adjusted Lerner index proposed by Koetter et al. (2012). The U-shape test is based on Lind and Mehlum (2010) and the p-value of the test statistic is reported between square brackets. 
Table 5: Market power and bank risk-taking: The nonlinear relationship between the Lerner index and loan loss reserves

\begin{tabular}{|c|c|c|c|c|c|c|}
\hline & $(1)$ & $(2)$ & $(3)$ & (4) & $(5)$ & (6) \\
\hline Dependent variable & $\begin{array}{c}\text { Loan loss } \\
\text { FE }\end{array}$ & $\begin{array}{c}\text { Loan loss } \\
\text { FE }\end{array}$ & $\begin{array}{c}\text { Loan loss } \\
\text { FE }\end{array}$ & $\begin{array}{c}\text { Loan loss } \\
\text { 2SLS }\end{array}$ & $\begin{array}{c}\text { Loan loss } \\
\text { 2SLS }\end{array}$ & $\begin{array}{c}\text { Loan loss } \\
\text { 2SLS }\end{array}$ \\
\hline Lerner & $\begin{array}{c}-28.659 \\
(17.547)\end{array}$ & $\begin{array}{c}-29.232 \\
(17.495)\end{array}$ & $\begin{array}{c}-19.250^{* *} \\
(8.709)\end{array}$ & $\begin{array}{c}-59.703^{* * *} \\
(21.534)\end{array}$ & $\begin{array}{c}58.714^{* * *} \\
(20.474)\end{array}$ & $\begin{array}{c}-51.906^{* * *} \\
(15.712)\end{array}$ \\
\hline Lerner*Lerner & $\begin{array}{c}24.365 \\
(18.393)\end{array}$ & $\begin{array}{c}26.052 \\
(18.689)\end{array}$ & $\begin{array}{l}13.090 \\
(9.821)\end{array}$ & $\begin{array}{c}42.663^{* *} \\
(19.790)\end{array}$ & $\begin{array}{c}42.568^{* *} \\
(19.187)\end{array}$ & $\begin{array}{c}39.232^{* *} \\
(15.614)\end{array}$ \\
\hline Inflation & & $\begin{array}{c}-0.774^{*} \\
(0.398)\end{array}$ & $\begin{array}{c}-0.842^{*} \\
(0.419)\end{array}$ & & $\begin{array}{l}-0.169 \\
(0.309)\end{array}$ & $\begin{array}{c}-0.102 \\
(0.280)\end{array}$ \\
\hline GDP growth & & $\begin{array}{c}-0.116 \\
(0.124)\end{array}$ & $\begin{array}{l}-0.036 \\
(0.163)\end{array}$ & & $\begin{array}{l}-0.185 \\
(0.143)\end{array}$ & $\begin{array}{l}-0.175 \\
(0.138)\end{array}$ \\
\hline Crisis dummy & $\begin{array}{c}4.666^{* * * *} \\
(1.391)\end{array}$ & $\begin{array}{c}4.822 \\
(4.095)\end{array}$ & $\begin{array}{l}13.002 \\
(8.514)\end{array}$ & $\begin{array}{c}4.593^{* * *} \\
(1.608)\end{array}$ & $\begin{array}{c}5.824^{* * * *} \\
(2.256)\end{array}$ & $\begin{array}{c}6.439^{* * * *} \\
(1.888)\end{array}$ \\
\hline Size & & & $\begin{array}{l}-3.585 \\
(2.901)\end{array}$ & & & $\begin{array}{c}1.035 \\
(1.133)\end{array}$ \\
\hline Non-interest income/total income & & & $\begin{array}{l}-3.860^{*} \\
(2.069)\end{array}$ & & & $\begin{array}{l}4.861^{* *} \\
(1.955)\end{array}$ \\
\hline Fixed assets/total assets & & & $\begin{array}{c}23.219 \\
(20.720)\end{array}$ & & & $\begin{array}{c}19.324 \\
(22.169)\end{array}$ \\
\hline Loans/total assets & & & $\begin{array}{c}6.614 \\
(10.228)\end{array}$ & & & $\begin{array}{l}-4.208 \\
(5.203)\end{array}$ \\
\hline Liquidity & & & $\begin{array}{c}0.036 \\
(0.055)\end{array}$ & & & $\begin{array}{l}-0.035 \\
(0.023)\end{array}$ \\
\hline U-shape test & $\begin{array}{c}1.00 \\
{[0.162]}\end{array}$ & $\begin{array}{c}1.11 \\
{[0.137]}\end{array}$ & $\begin{array}{c}0.53 \\
{[0.301]}\end{array}$ & $\begin{array}{c}1.29 \\
{[0.099]}\end{array}$ & $\begin{array}{c}1.33 \\
{[0.091]}\end{array}$ & $\begin{array}{c}1.56 \\
{[0.060]}\end{array}$ \\
\hline $\begin{array}{l}\text { Turning point } \\
95 \% \text { confidence interval, Fieller method }\end{array}$ & - & - & - & $\begin{array}{c}0.699 \\
{[0.585 ; 2.478]}\end{array}$ & $\begin{array}{c}0.689 \\
{[0.571 ; 2.057]}\end{array}$ & $\begin{array}{c}0.661 \\
{[0.552 ; 1.321]}\end{array}$ \\
\hline Year fixed effects & Yes & Yes & Yes & Yes & Yes & Yes \\
\hline Observations & 349 & 349 & 349 & 341 & 341 & 341 \\
\hline R-squared & 0.462 & 0.484 & 0.553 & 0.035 & 0.084 & 0.306 \\
\hline Number of banks & 38 & 38 & 38 & 38 & 38 & 38 \\
\hline Hansen J-OverID test [p-value] & - & - & - & 0.286 & 0.299 & 0.215 \\
\hline
\end{tabular}

Note: Constant included but not reported. Robust standard errors clustered at bank level are reported below their coefficient estimates. The Hansen test evaluates the joint validity of instruments used. *, ** and ${ }^{* * *}$ indicate statistical significance at the $10 \%, 5 \%$ and $1 \%$ levels, respectively. The Lerner index refers to the adjusted Lerner index proposed by Koetter et al. (2012). The U-shape test is based on Lind and Mehlum (2010) and the p-value of the test statistic is reported between square brackets. 
Table 6: Market power and bank risk-taking: The nonlinear relationship between the market share and the Z-score

\begin{tabular}{|c|c|c|c|c|c|c|}
\hline & $(1)$ & $(2)$ & $(3)$ & $(4)$ & $(5)$ & $(6)$ \\
\hline Dependent variable & $\begin{array}{c}\text { Z-score } \\
\text { FE }\end{array}$ & $\begin{array}{c}\text { Z-score } \\
\text { FE }\end{array}$ & $\begin{array}{c}\text { Z-score } \\
\text { FE }\end{array}$ & $\begin{array}{c}\text { Z-score } \\
2 \text { SLS }\end{array}$ & $\begin{array}{c}\text { Z-score } \\
2 \text { SLS }\end{array}$ & $\begin{array}{c}\text { Z-score } \\
2 \mathrm{SLS}\end{array}$ \\
\hline Market share & $\begin{array}{l}-0.006 \\
(0.071)\end{array}$ & $\begin{array}{l}-0.005 \\
(0.068)\end{array}$ & $\begin{array}{c}0.028 \\
(0.069)\end{array}$ & $\begin{array}{c}0.005 \\
(0.086)\end{array}$ & $\begin{array}{c}0.006 \\
(0.084)\end{array}$ & $\begin{array}{c}0.065 \\
(0.075)\end{array}$ \\
\hline Market share*Market share & $\begin{array}{c}0.000 \\
(0.001)\end{array}$ & $\begin{array}{c}0.000 \\
(0.001)\end{array}$ & $\begin{array}{c}0.000 \\
(0.001)\end{array}$ & $\begin{array}{c}0.000 \\
(0.001)\end{array}$ & $\begin{array}{c}0.000 \\
(0.001)\end{array}$ & $\begin{array}{l}-0.000 \\
(0.001)\end{array}$ \\
\hline Inflation & & $\begin{array}{c}0.050 \\
(0.070)\end{array}$ & $\begin{array}{c}0.012 \\
(0.065)\end{array}$ & & $\begin{array}{c}0.049 \\
(0.069)\end{array}$ & $\begin{array}{c}0.006 \\
(0.065)\end{array}$ \\
\hline GDP growth & & $\begin{array}{l}-0.048 \\
(0.047)\end{array}$ & $\begin{array}{c}-0.042 \\
(0.048)\end{array}$ & & $\begin{array}{l}-0.041 \\
(0.044)\end{array}$ & $\begin{array}{l}-0.037 \\
(0.045)\end{array}$ \\
\hline Crisis dummy & $\begin{array}{c}-2.121^{* * *} \\
(0.639)\end{array}$ & $\begin{array}{c}-0.263 \\
(0.793)\end{array}$ & $\begin{array}{l}-0.579 \\
(1.292)\end{array}$ & $\begin{array}{c}-1.038^{* * *} \\
(0.297)\end{array}$ & $\begin{array}{c}-1.061^{* * *} \\
(0.405)\end{array}$ & $\begin{array}{c}-1.108^{* * *} \\
(0.411)\end{array}$ \\
\hline Size & & & $\begin{array}{c}0.019 \\
(0.162)\end{array}$ & & & $\begin{array}{c}-0.070 \\
(0.180)\end{array}$ \\
\hline Non-interest income/total income & & & $\begin{array}{l}-0.504 \\
(0.644)\end{array}$ & & & $\begin{array}{l}-0.558 \\
(0.607)\end{array}$ \\
\hline Fixed assets/total assets & & & $\begin{array}{c}3.239 \\
(9.939)\end{array}$ & & & $\begin{array}{c}4.030 \\
(9.518)\end{array}$ \\
\hline Loans/total assets & & & $\begin{array}{l}3.616^{*} \\
(1.865)\end{array}$ & & & $\begin{array}{l}3.467^{*} \\
(1.796)\end{array}$ \\
\hline Liquidity & & & $\begin{array}{c}0.012 \\
(0.014)\end{array}$ & & & $\begin{array}{c}0.012 \\
(0.013)\end{array}$ \\
\hline U-shape test & $\begin{array}{c}0.09 \\
{[0.464]}\end{array}$ & $\begin{array}{c}0.08 \\
{[0.47]}\end{array}$ & $\begin{array}{l}\text { Ext. outside } \\
\text { interval }\end{array}$ & $\begin{array}{l}\text { Ext. outside } \\
\text { interval }\end{array}$ & $\begin{array}{c}\text { Ext. outside } \\
\text { interval }\end{array}$ & $\begin{array}{c}\text { Ext. outside } \\
\text { interval }\end{array}$ \\
\hline Turning point & - & - & - & - & - & - \\
\hline $95 \%$ confidence interval, Fieller method & - & - & - & - & - & - \\
\hline Year fixed effects & Yes & Yes & Yes & Yes & Yes & Yes \\
\hline Observations & 370 & 370 & 366 & 369 & 369 & 365 \\
\hline R-squared & 0.329 & 0.333 & 0.362 & 0.330 & 0.333 & 0.364 \\
\hline Number of banks & 40 & 40 & 39 & 40 & 40 & 39 \\
\hline Hansen J-OverID test [p-value] & - & - & - & 0.236 & 0.251 & 0.178 \\
\hline
\end{tabular}

Note: Constant included but not reported. Robust standard errors clustered at bank level are reported below their coefficient estimates. The Hansen test evaluates the joint validity of instruments used. *, ${ }^{* *}$ and ${ }^{* * *}$ indicate statistical significance at the $10 \%, 5 \%$ and $1 \%$ levels, respectively. The U-shape test is based on Lind and Mehlum (2010) and the p-value of the test statistic is reported between square brackets. Ext. outside interval means that the extremum point (i.e. the turning point) is outside the interval, then we cannot reject the null hypothesis of a monotone relationship. 
Table 7: Market power and bank risk-taking: The nonlinear relationship between the market share and loan loss reserves

\begin{tabular}{|c|c|c|c|c|c|c|}
\hline & $(1)$ & $(2)$ & $(3)$ & $(4)$ & $(5)$ & $(6)$ \\
\hline Dependent variable & $\begin{array}{c}\text { Loan loss } \\
\text { FE }\end{array}$ & $\begin{array}{c}\text { Loan loss } \\
\text { FE }\end{array}$ & $\begin{array}{c}\text { Loan loss } \\
\text { FE }\end{array}$ & $\begin{array}{c}\text { Loan loss } \\
\text { 2SLS }\end{array}$ & $\begin{array}{c}\text { Loan loss } \\
\text { 2SLS }\end{array}$ & $\begin{array}{c}\text { Loan loss } \\
\text { 2SLS }\end{array}$ \\
\hline Market share & $\begin{array}{c}-1.649^{* *} \\
(0.686)\end{array}$ & $\begin{array}{c}-1.611^{* *} \\
(0.676)\end{array}$ & $\begin{array}{c}-1.557^{* * *} \\
(0.568)\end{array}$ & $\begin{array}{c}-0.798^{* *} \\
(0.317)\end{array}$ & $\begin{array}{c}-0.752^{* *} \\
(0.310)\end{array}$ & $\begin{array}{c}-0.694^{* * *} \\
(0.204)\end{array}$ \\
\hline Market share* Market share & $\begin{array}{c}0.016^{* *} \\
(0.007)\end{array}$ & $\begin{array}{c}0.016^{* *} \\
(0.007)\end{array}$ & $\begin{array}{c}0.015^{* * *} \\
(0.006)\end{array}$ & $\begin{array}{c}0.009^{* * * *} \\
(0.003)\end{array}$ & $\begin{array}{c}0.008^{* * *} \\
(0.003)\end{array}$ & $\begin{array}{c}0.007^{* * * *} \\
(0.002)\end{array}$ \\
\hline Inflation & & $\begin{array}{c}-0.604^{* *} \\
(0.286)\end{array}$ & $\begin{array}{c}-0.679^{* *} \\
(0.332)\end{array}$ & & $\begin{array}{c}-0.396^{*} \\
(0.215)\end{array}$ & $\begin{array}{c}-0.276 \\
(0.203)\end{array}$ \\
\hline GDP growth & & $\begin{array}{c}0.072 \\
(0.158)\end{array}$ & $\begin{array}{c}0.053 \\
(0.143)\end{array}$ & & $\begin{array}{l}-0.058 \\
(0.108)\end{array}$ & $\begin{array}{c}-0.026 \\
(0.098)\end{array}$ \\
\hline Crisis dummy & $\begin{array}{l}-1.699 \\
(3.032)\end{array}$ & $\begin{array}{l}-4.874 \\
(3.352)\end{array}$ & $\begin{array}{l}-1.811 \\
(4.072)\end{array}$ & $\begin{array}{l}2.296^{*} \\
(1.302)\end{array}$ & $\begin{array}{c}3.897^{* *} \\
(1.602)\end{array}$ & $\begin{array}{c}4.407 * * * \\
(1.513)\end{array}$ \\
\hline Size & & & $\begin{array}{c}-0.583 \\
(1.180)\end{array}$ & & & $\begin{array}{c}0.730 \\
(0.687)\end{array}$ \\
\hline Non-interest income/total income & & & $\begin{array}{c}-4.438^{*} \\
(2.560)\end{array}$ & & & $\begin{array}{l}5.093^{* *} \\
(2.350)\end{array}$ \\
\hline Fixed assets/total assets & & & $\begin{array}{c}16.946 \\
(33.153)\end{array}$ & & & $\begin{array}{l}30.684^{*} \\
(16.915)\end{array}$ \\
\hline Loans/total assets & & & $\begin{array}{l}-3.592 \\
(5.070)\end{array}$ & & & $\begin{array}{l}-4.805 \\
(4.134)\end{array}$ \\
\hline Liquidity & & & $\begin{array}{l}-0.041 \\
(0.029)\end{array}$ & & & $\begin{array}{c}-0.047^{* *} \\
(0.022) \\
\end{array}$ \\
\hline U-shape test & $\begin{array}{c}2.40 \\
{[0.010]}\end{array}$ & $\begin{array}{c}2.36 \\
{[0.011]}\end{array}$ & $\begin{array}{c}2.66 \\
{[0.005]}\end{array}$ & $\begin{array}{c}2.52 \\
{[0.006]}\end{array}$ & $\begin{array}{c}2.43 \\
{[0.007]}\end{array}$ & $\begin{array}{c}3.40 \\
{[0.000]}\end{array}$ \\
\hline $\begin{array}{l}\text { Turning point } \\
95 \% \text { confidence interval, Fieller method }\end{array}$ & $\begin{array}{c}50.90 \\
{[44.48 ; 57.35]}\end{array}$ & $\begin{array}{c}51.58 \\
{[44.68 ; 59.89]}\end{array}$ & $\begin{array}{c}51.50 \\
{[46.16 ; 58.70]}\end{array}$ & $\begin{array}{c}45.69 \\
{[31.89 ; 50.88]}\end{array}$ & $\begin{array}{c}47.15 \\
{[31.54 ; 52.58]}\end{array}$ & $\begin{array}{c}47.21 \\
{[38.04 ; 53.08]}\end{array}$ \\
\hline Year fixed effects & Yes & Yes & Yes & Yes & Yes & Yes \\
\hline Observations & 368 & 368 & 368 & 365 & 365 & 365 \\
\hline R-squared & 0.583 & 0.594 & 0.608 & 0.582 & 0.593 & 0.633 \\
\hline Number of banks & 38 & 38 & 38 & 38 & 38 & 38 \\
\hline Hansen J-OverID test [p-value] & - & - & - & 0.196 & 0.194 & 0.0799 \\
\hline
\end{tabular}

Note: Constant included but not reported. Robust standard errors clustered at bank level are reported below their coefficient estimates. The Hansen test evaluates the joint validity of instruments used. *, ** and $* * *$ indicate statistical significance at the $10 \%, 5 \%$ and $1 \%$ levels, respectively. The U-shape test is based on Lind and Mehlum (2010) and the p-value of the test statistic is reported between square brackets.

\section{Robustness checks}

We test the robustness of our results in several ways. First, we consider two additional proxies for bank risk. Then, following Soedarmono et al. (2011), we use a Z-score measure based on the return on equity $(Z R O E)$. We also replace the loan loss reserves as a percentage of gross loans with impaired loans as a percentage of gross loans. The results obtained with these two alternative lefthand side variables are presented in table 8 . To save space, we do not report the coefficient estimates associated with the control variables, and we only focus on the results obtained with the FE estimator. Detailed results are available upon request. The results that we obtain are very similar to those reported above, and we still find an inverse U-shaped relationship between the Lerner index and our ZROE measure of bank stability, and a statistically significant U-shaped relationship between market share and our proxy for credit risk, which is impaired loans as a percentage of gross loans. Consistent with our previous findings, the turning points are close to 0.62 for the Lerner index and between 
$51 \%$ and $54 \%$ for the market share.

Table 8: Market power and bank risk-taking: Results obtained with alternative measures of risk

\begin{tabular}{|c|c|c|c|c|c|c|}
\hline & (1) & 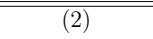 & $(3)$ & (1) & (2) & 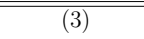 \\
\hline Dependent variable & $\begin{array}{c}\text { ZROE } \\
\text { FE }\end{array}$ & $\begin{array}{l}\text { ZROE } \\
\text { FE }\end{array}$ & $\begin{array}{l}\text { ZROE } \\
\text { FE }\end{array}$ & $\begin{array}{c}\text { Imp. Loans } \\
\mathrm{FE}\end{array}$ & $\begin{array}{c}\text { Imp. Loans } \\
\mathrm{FE}\end{array}$ & $\begin{array}{l}\text { Imp. Loans } \\
\text { FE }\end{array}$ \\
\hline Lerner & $\begin{array}{c}4.866^{* * *} \\
(1.223)\end{array}$ & $\begin{array}{c}4.817^{* * *} \\
(1.234)\end{array}$ & $\begin{array}{c}5.054^{* * *} \\
(1.308)\end{array}$ & $\begin{array}{l}-33.889 \\
(23.139)\end{array}$ & $\begin{array}{l}-38.433 \\
(23.563)\end{array}$ & $\begin{array}{c}-22.507^{*} \\
(13.142)\end{array}$ \\
\hline Lerner*Lerner & $\begin{array}{c}-3.930^{* * *} \\
(1.372) \\
\end{array}$ & $\begin{array}{c}-3.874^{* * *} \\
(1.407) \\
\end{array}$ & $\begin{array}{c}-4.020^{* *} \\
(1.511)\end{array}$ & $\begin{array}{c}19.313 \\
(23.235) \\
\end{array}$ & $\begin{array}{c}27.620 \\
(24.324) \\
\end{array}$ & $\begin{array}{c}6.435 \\
(15.164) \\
\end{array}$ \\
\hline U-shape test & $\begin{array}{c}1.77 \\
{[0.042]}\end{array}$ & $\begin{array}{c}1.67 \\
{[0.051]}\end{array}$ & $\begin{array}{c}1.58 \\
{[0.061]}\end{array}$ & $\begin{array}{c}0.16 \\
{[0.438]}\end{array}$ & $\begin{array}{c}0.62 \\
{[0.27]}\end{array}$ & $\begin{array}{l}\text { Ext. outside } \\
\text { interval }\end{array}$ \\
\hline Turning point & 0.619 & 0.621 & 0.628 & - & - & - \\
\hline $\begin{array}{l}95 \% \text { confidence interval, Fieller method } \\
\text { Ōbservations }\end{array}$ & {$[0.500 ; 1.133]$} & {$[0.498 ; 1.232]$} & {$[0.504 ; 1.349]$} & $-\overline{-} \overline{5} \overline{3}-$ & $-\overline{-}^{-} \overline{3}^{--}$ & $--\overline{\overline{2}} \overline{5} \overline{3}^{--}$ \\
\hline R-squared & 0.428 & 0.428 & 0.466 & 0.479 & 0.506 & 0.574 \\
\hline Number of banks & 40 & 40 & 39 & 34 & 34 & 34 \\
\hline Dependent variable & $\begin{array}{l}\text { ZROE } \\
\text { FE }\end{array}$ & $\begin{array}{l}\text { ZROE } \\
\text { FE }\end{array}$ & $\begin{array}{l}\text { ZROE } \\
\text { FE }\end{array}$ & $\begin{array}{l}\text { Imp. Loans } \\
\text { FE }\end{array}$ & $\begin{array}{l}\text { Imp. Loans } \\
\text { FE }\end{array}$ & $\begin{array}{l}\text { Imp. Loans } \\
\text { FE }\end{array}$ \\
\hline Market share & $\begin{array}{c}-0.022 \\
(0.058)\end{array}$ & $\begin{array}{l}-0.020 \\
(0.055)\end{array}$ & $\begin{array}{l}0.036 \\
(0.056)\end{array}$ & $\begin{array}{c}-2.354^{* *} \\
(0.944)\end{array}$ & $\begin{array}{c}-2.270^{* *} \\
(0.931)\end{array}$ & $\begin{array}{c}-1.918^{* *} \\
(0.737)\end{array}$ \\
\hline Market share* Market share & $\begin{array}{c}0.001 \\
(0.001)\end{array}$ & $\begin{array}{c}0.001 \\
(0.001)\end{array}$ & $\begin{array}{l}0.000 \\
(0.001)\end{array}$ & $\begin{array}{c}0.023^{* *} \\
(0.009)\end{array}$ & $\begin{array}{c}0.021^{* *} \\
(0.009)\end{array}$ & $\begin{array}{l}0.018^{* *} \\
(0.007)\end{array}$ \\
\hline U-shape test & $\begin{array}{c}0.37 \\
{[0.355]}\end{array}$ & $\begin{array}{c}0.37 \\
{[0.356]}\end{array}$ & $\begin{array}{l}\text { Ext. outside } \\
\text { interval }\end{array}$ & $\begin{array}{c}2.49 \\
{[0.009]}\end{array}$ & $\begin{array}{c}2.42 \\
{[0.010]}\end{array}$ & $\begin{array}{c}2.60 \\
{[0.007]}\end{array}$ \\
\hline Turning point & - & - & - & 52.30 & 53.32 & 51.85 \\
\hline $\begin{array}{l}95 \% \text { confidence interval, Fieller method } \\
\text { Ōbservations }\end{array}$ & $\overline{3} \overline{2} \overline{1}-$ & $-\overline{3} \overline{1}-$ & $-\overline{3} \overline{16}-$ & {$[43.39 ; 59.06]$} & {$[43.61 ; 63.64]$} & {$[41.91 ; 60.66]$} \\
\hline R-squared & 0.324 & 0.332 & 0.372 & 0.529 & 0.539 & 0.553 \\
\hline Number of banks & 40 & 40 & 39 & 34 & 34 & 34 \\
\hline
\end{tabular}

Note: Constant included but not reported. Year fixed effects included. Robust standard errors clustered at bank level are reported below their coefficient estimates. ${ }^{*},{ }^{* *}$ and ${ }^{* * *}$ indicate statistical significance at the $10 \%, 5 \%$ and $1 \%$ levels, respectively. Specification (1) includes crisis dummy as control variable, specification (2) includes crisis dummy, inflation, and GDP growth as control variables, while specification (3) includes all control variables. Control variables are lagged one period. The Lerner index refers to the adjusted Lerner index proposed by Koetter et al. (2012). The U-shape test is based on Lind and Mehlum (2010) and the p-value of the test statistic is reported between square brackets. Ext. outside interval means that the extremum point (i.e. the turning point) is outside the interval, then we cannot reject the null hypothesis of a monotone relationship.

We also test the sensitivity of our results by considering three alternative measures of the Lerner index and one alternative measure of market share. The first alternative measure of the Lerner index uses a three-year moving average. This measure aims to smooth the cyclical fluctuations of the Lerner index because the market power of a bank is not likely to change radically in the short-run, as argued by Leroy and Lucotte (2017). Second, we follow Maudos and de Guevara (2007) and Turk-Ariss (2010) by re-estimating the translog cost function (equation 2) with funding costs excluded. It may be expected that banks with a high level of market power, especially those with a high level of deposit market power, are able to raise funds at a cheap cost. In this case, as Maudos and de Guevara (2007) argue, including financial costs and consequently the price of deposits in the cost function captures the effect of market power in banking and may bias the results. By excluding funding costs, we are likely to get a clean proxy for pricing power that is not distorted by deposit market power (Turk-Ariss, 2010). As 
before, the two-input cost function is estimated using an SFA, and we apply the correction proposed by Koetter et al. (2012) to compute the funding-adjusted Lerner index. In a very few cases values can be obtained empirically for the Lerner index that are outside the 0 to 1 range. In our case, we have a total of 29 observations below zero, and no observations above one (see figure A7 and table A2 in Appendix). Rather than treating these observations as outliers and dropping them, we code them equal to zero, and then consider a left-censored Lerner index. Finally, we use an alternative measure of market share that does not only look at bank assets, but also considers deposit and loan market power. This index is called global market share and is equal for each bank to the average of its market shares for assets, loans, and deposits. Correlations between our different proxies for market power for each Baltic country are illustrated in figure A9. The results are reported in tables 9 and 10. As previously, we only report the coefficient estimates of our variables of interest. The results we obtain confirm our previous findings.

Table 9: Market power and the Z-score: Results obtained with alternative proxies for market power

\begin{tabular}{|c|c|c|c|c|c|c|c|c|}
\hline & (1) & $\overline{(2)}$ & 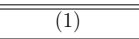 & 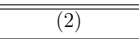 & 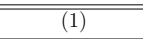 & $(2)$ & (1) & 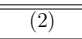 \\
\hline Dependent variable & $\begin{array}{c}\text { Z-score } \\
\text { FE }\end{array}$ & $\begin{array}{l}\text { Z-score } \\
\text { IV }\end{array}$ & $\begin{array}{c}\text { Z-score } \\
\text { FE }\end{array}$ & $\begin{array}{l}\text { Z-score } \\
\text { IV }\end{array}$ & $\begin{array}{c}\text { Z-score } \\
\text { FE }\end{array}$ & $\begin{array}{c}\text { Z-score } \\
\text { IV }\end{array}$ & $\begin{array}{c}\text { Z-score } \\
\text { FE }\end{array}$ & $\begin{array}{c}\text { Z-score } \\
\text { IV }\end{array}$ \\
\hline Lerner 1 & $\begin{array}{c}7.152^{* * *} \\
(1.534)\end{array}$ & $\begin{array}{c}9.565^{* * *} \\
(2.212)\end{array}$ & & & & & & \\
\hline Lerner $1 *$ Lerner 1 & $\begin{array}{c}-5.127^{* * *} \\
(1.612)\end{array}$ & $\begin{array}{c}-6.572^{* * *} \\
(2.472)\end{array}$ & & & & & & \\
\hline Lerner 2 & & & $\begin{array}{c}5.370^{* * *} \\
(1.210)\end{array}$ & $\begin{array}{c}15.213^{* * *} \\
(3.122)\end{array}$ & & & & \\
\hline Lerner $2 *$ Lerner2 & & & $\begin{array}{c}-4.759^{* * *} \\
(1.456)\end{array}$ & $\begin{array}{c}-12.774^{* * *} \\
(2.984)\end{array}$ & & & & \\
\hline Lerner 3 & & & & & $\begin{array}{c}5.202 * * * \\
(1.247)\end{array}$ & $\begin{array}{c}14.894^{* * *} \\
(3.194)\end{array}$ & & \\
\hline Lerner3*Lerner3 & & & & & $\begin{array}{c}-4.478^{* * *} \\
(1.473)\end{array}$ & $\begin{array}{c}-12.323^{* * *} \\
(3.085)\end{array}$ & & \\
\hline Global Market share & & & & & & & $\begin{array}{c}0.078 \\
(0.060)\end{array}$ & $\begin{array}{c}0.133^{* *} \\
(0.066)\end{array}$ \\
\hline Global Market share* Global market share & & & & & & & $\begin{array}{l}-0.000 \\
(0.001)\end{array}$ & $\begin{array}{l}-0.001 \\
(0.001)\end{array}$ \\
\hline U-shape test & $\begin{array}{c}1.51 \\
{[0.069]}\end{array}$ & $\begin{array}{c}1.12 \\
{[0.131]}\end{array}$ & $\begin{array}{c}2.26 \\
{[0.014]}\end{array}$ & $\begin{array}{c}3.19 \\
{[0.001]}\end{array}$ & $\begin{array}{c}2.04 \\
{[0.024]}\end{array}$ & $\begin{array}{c}2.91 \\
{[0.002]}\end{array}$ & $\begin{array}{c}0.01 \\
{[0.494]}\end{array}$ & $\begin{array}{c}0.30 \\
{[0.381]}\end{array}$ \\
\hline Turning point & 0.697 & - & 0.564 & 0.595 & 0.580 & 0.604 & - & - \\
\hline $95 \%$ confidence interval, Fieller method & {$[0.561 ; 1.182]$} & - & {$[0.472 ; 0.865]$} & {$[0.518 ; 0.725]$} & {$[0.480 ; 0.964]$} & {$[0.525 ; 0.755]$} & - & - \\
\hline Year fixed éffects & $\bar{Y}^{-} \mathrm{es}^{-1-}$ & $\bar{Y} \overline{e s}^{-}$ & ${ }^{\prime} \overline{Y s}^{-\cdots-}$ & Y'es & -1 Yes -1 & Y's & $\bar{Y}_{\mathrm{es}}^{-}$ & $\bar{Y} \bar{Y} \bar{L}^{-}$ \\
\hline Observations & 351 & 350 & 346 & 339 & 346 & 339 & 364 & 363 \\
\hline R-squared & 0.444 & 0.497 & 0.451 & 0.218 & 0.448 & 0.228 & 0.375 & 0.381 \\
\hline Number of banks & 39 & 39 & 39 & 39 & 39 & 39 & 39 & 39 \\
\hline Hansen J-OverID test [p-value] & - & 0.104 & - & 0.0927 & - & 0.108 & - & 0.256 \\
\hline
\end{tabular}

Note: Constant included but not reported. Robust standard errors clustered at bank level are reported below their coefficient estimates. ${ }^{*}, * *$ and $* * *$ indicate statistical significance at the $10 \%, 5 \%$ and $1 \%$ levels, respectively. Specifications (1) and (2) includes all control variables. Specification (1) is estimated using the FE estimator, while specification (2) is estimated using the 2SLS estimator. Control variables are lagged one period. Lerner 1 corresponds to the 3 -year moving average Lerner index, Lerner 2 to the funding-adjusted Lerner index, Lerner 3 to the left-censored Lerner index, and Global market share to the market share calculated by considering assets, loans and deposits. The U-shape test is based on Lind and Mehlum (2010) and the p-value of the test statistic is reported between square brackets. 
Table 10: Market power and loan loss reserves: Results obtained with alternative

\begin{tabular}{|c|c|c|c|c|c|c|c|c|}
\hline proxies for market po & Wer(1) & $(2)$ & (1) & $(2)$ & (1) & $\overline{~(2)}$ & (1) & (2) \\
\hline Dependent variable & $\begin{array}{c}\text { Loan loss } \\
\mathrm{FE}\end{array}$ & $\begin{array}{l}\text { Loan loss } \\
\text { IV }\end{array}$ & $\begin{array}{c}\text { Loan loss } \\
\text { FE }\end{array}$ & $\begin{array}{c}\text { Loan loss } \\
\text { IV }\end{array}$ & $\begin{array}{c}\text { Loan loss } \\
\text { FE }\end{array}$ & $\begin{array}{c}\text { Loan loss } \\
\text { IV }\end{array}$ & $\begin{array}{c}\text { Loan loss } \\
\mathrm{FE}\end{array}$ & $\begin{array}{c}\text { Loan loss } \\
\text { IV }\end{array}$ \\
\hline Lerner 1 & $\begin{array}{c}-54.098^{* * * *} \\
(17.699)\end{array}$ & $\begin{array}{c}-50.048^{* * *} \\
(12.095)\end{array}$ & & & & & & \\
\hline Lerner $1 *$ Lerner 1 & $\begin{array}{c}41.918^{* * * *} \\
(15.154)\end{array}$ & $\begin{array}{c}39.118^{* * * *} \\
(11.808)\end{array}$ & & & & & & \\
\hline Lerner 2 & & & $\begin{array}{c}-15.442^{* *} \\
(7.522)\end{array}$ & $\begin{array}{c}-51.876^{* * *} \\
(16.980)\end{array}$ & & & & \\
\hline Lerner $2 *$ Lerner2 & & & $\begin{array}{c}8.634 \\
(9.385)\end{array}$ & $\begin{array}{c}38.018^{* *} \\
(16.209)\end{array}$ & & & & \\
\hline Lerner 3 & & & & & $\begin{array}{c}-16.570^{* *} \\
(7.892)\end{array}$ & $\begin{array}{c}-51.129^{* * *} \\
(16.748)\end{array}$ & & \\
\hline Lerner3*Lerner3 & & & & & $\begin{array}{c}9.712 \\
(9.466)\end{array}$ & $\begin{array}{c}37.320^{* *} \\
(16.092)\end{array}$ & & \\
\hline Global Market share & & & & & & & $\begin{array}{c}-1.018^{* *} \\
(0.407)\end{array}$ & $\begin{array}{c}-0.821^{* * * *} \\
(0.194)\end{array}$ \\
\hline Global Market share*Global market share & & & & & & & $\begin{array}{c}0.010^{* *} \\
(0.004) \\
\end{array}$ & $\begin{array}{c}0.009^{* * *} \\
(0.002) \\
\end{array}$ \\
\hline U-shape test & $\begin{array}{c}2.09 \\
{[0.021]}\end{array}$ & $\begin{array}{c}2.22 \\
{[0.013]}\end{array}$ & $\begin{array}{c}0.11 \\
{[0.456]}\end{array}$ & $\begin{array}{c}1.42 \\
{[0.078]}\end{array}$ & $\begin{array}{c}0.19 \\
{[0.424]}\end{array}$ & $\begin{array}{c}1.38 \\
{[0.084]}\end{array}$ & $\begin{array}{c}2.50 \\
{[0.008]}\end{array}$ & $\begin{array}{c}4.24 \\
{[0.000]}\end{array}$ \\
\hline Turning point & 0.645 & 0.639 & - & 0.682 & - & 0.685 & 51.56 & $\begin{array}{c}45.79 \\
\end{array}$ \\
\hline $95 \%$ confidence interval, Fieller method & {$[0.543 ; 0.927]$} & {$[0.561 ; 0.871]$} & -- & {$[0.568 ; 1.615]$} & 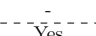 & {$[0.568 ; 1.721]$} & {$[45.59 ; 56.99]$} & {$[38.46 ; 51.86]$} \\
\hline Year fixed effects & Yes & Yेes & Y'- Yes & Ȳes & Yes & Yes & Yes & Yes \\
\hline $\begin{array}{l}\text { Observations } \\
\text { R-squared }\end{array}$ & $\begin{array}{c}355 \\
0.645\end{array}$ & $\begin{array}{c}352 \\
0.684\end{array}$ & $\begin{array}{c}349 \\
0.543\end{array}$ & $\begin{array}{c}341 \\
0.271\end{array}$ & $\begin{array}{c}349 \\
0.546\end{array}$ & $\begin{array}{c}341 \\
0.301\end{array}$ & $\begin{array}{c}364 \\
0.606\end{array}$ & $\begin{array}{c}363 \\
0.638\end{array}$ \\
\hline Number of banks & 38 & 38 & 38 & 38 & 38 & 38 & 38 & 38 \\
\hline Hansen J-OverID test [p-value] & - & 0.202 & - & 0.168 & - & 0.156 & - & 0.0867 \\
\hline
\end{tabular}

Note: Constant included but not reported. Robust standard errors clustered at bank level are reported below their coefficient estimates. ${ }^{*}, * *$ and $* * *$ indicate statistical significance at the $10 \%, 5 \%$ and $1 \%$ levels, respectively. Specifications (1) and (2) includes all control variables. Specification (1) is estimated using the FE estimator, while specification (2) is estimated using the 2SLS estimator. Control variables are lagged one period. Lerner 1 corresponds to the 3 -year moving average Lerner index, Lerner 2 to the funding-adjusted Lerner index, Lerner 3 to the left-censored Lerner index, and Global market share to the market share calculated by considering assets, loans and deposits. The U-shape test is based on Lind and Mehlum (2010) and the p-value of the test statistic is reported between square brackets.

Third, we re-estimate our benchmark nonlinear specification (equation 6) by considering a robust regression approach. The idea behind the robust regression is to down-weight the influence of high leverage data points and outliers to provide a better fit of the data ${ }^{7}$. Our results, reported in table 11, confirm the substance of the previous results. We find a very significant nonlinear relationship between the Lerner index and our two proxies for bank risk, though this relationship appears not to be statistically significant when we consider market share and its squared term as right-hand side variables. This last result could nonetheless easily be explained by the distribution of the market share series, where there is consistently a large left tail (see figure A8), which implies that

\footnotetext{
${ }^{7} \mathrm{~A}$ robust regression is an alternative approach used when the data contain some outliers or high leverage data points. It is a compromise between excluding these points entirely from the analysis and including all the data points and treating them all equally in the regression. In practice, robust regression works by assigning a weight to each data point. Weighting is done automatically and iteratively using a process called iteratively reweighted least squares. In the first iteration, each point is assigned an equal weight and model coefficients are estimated using ordinary least squares (OLS). At subsequent iterations, weights are recomputed so that points farther from the model predictions in the previous iteration are given a lower weight. The model coefficients are then recomputed using weighted least squares. The process continues until the values of the coefficient estimates converge within a specified tolerance.
} 
banks with a large market share are down-weighted.

Table 11: Market power and bank risk-taking: Results obtained using a robust

\begin{tabular}{|c|c|c|c|c|c|c|}
\hline regression approach & (1) & $(2)$ & $(3)$ & (1) & $(2)$ & $(3)$ \\
\hline Dependent variable & Z-score & Z-score & Z-score & Loan loss & Loan loss & Loan loss \\
\hline \multirow[t]{2}{*}{ Lerner } & $6.293^{* * *}$ & $6.251^{* * *}$ & $6.308^{* * *}$ & $-7.279^{* * *}$ & $-6.954^{* * *}$ & $-9.560^{* * *}$ \\
\hline & $(0.754)$ & $(0.762)$ & $(0.714)$ & $(1.571)$ & $(1.535)$ & $(1.532)$ \\
\hline \multirow[t]{2}{*}{ Lerner*Lerner } & $-5.780 * * *$ & $-5.709 * * *$ & $-5.888 * * *$ & $4.667^{* *}$ & $4.183^{* *}$ & $6.717^{* * *} *$ \\
\hline & $(0.854)$ & $(0.872)$ & $(0.822)$ & $(1.811)$ & $(1.785)$ & $(1.790)$ \\
\hline \multirow[t]{2}{*}{ U-shape test } & 5.00 & 4.77 & 5.33 & 0.84 & 0.56 & 1.65 \\
\hline & {$[0.000]$} & {$[0.000]$} & {$[0.000]$} & {$[0.2]$} & {$[0.289]$} & {$[0.049]$} \\
\hline Turning point & 0.544 & 0.547 & 0.535 & - & - & 0.711 \\
\hline $95 \%$ confidence interval, Fieller method & {$[0.494 ; 0.618]$} & {$[0.495 ; 0.627]$} & {$[0.488 ; 0.604]$} & - & - & {$[0.587 ; 1.071$} \\
\hline Ōbservations & $--\overline{3} 50--1$ & ---350 & $-3 \overline{4} 6$ & $\overline{349}-$ & $\overline{3} \overline{4} 9$ & $--\overline{3} \overline{4} 9^{--}$ \\
\hline R-squared & 0.442 & 0.443 & 0.520 & 0.650 & 0.660 & 0.713 \\
\hline Dependent variable & Z-score & Z-score & Z-score & Loan loss & Loan loss & Loan loss \\
\hline \multirow[t]{2}{*}{ Market share } & 0.008 & 0.007 & -0.001 & -0.003 & -0.006 & $-0.079^{* *}$ \\
\hline & $(0.010)$ & $(0.011)$ & $(0.018)$ & $(0.020)$ & $(0.020)$ & $(0.039)$ \\
\hline \multirow[t]{2}{*}{ Market share*Market share } & 0.000 & 0.000 & 0.000 & -0.000 & -0.000 & 0.001 \\
\hline & $(0.000)$ & $(0.000)$ & $(0.000)$ & $(0.000)$ & $(0.000)$ & $(0.000)$ \\
\hline \multirow[t]{2}{*}{ U-shape test } & Ext. outside & Ext. outside & 0.04 & Ext. outside & Ext. outside & 0.93 \\
\hline & interval & interval & {$[0.483]$} & interval & interval & {$[0.176]$} \\
\hline Turning point & - & - & - & - & - & - \\
\hline $95 \%$ confidence interval, Fieller method & - & - & - & - & - & - \\
\hline Óbservations & $\overline{3} \overline{7} 0^{-}$ & ${ }^{-} 3 \overline{7} \overline{0}^{-}$ & $-\overline{3} 66^{-}$ & $-\overline{368}-$ & $\overline{3} \overline{6} \overline{8}$ & $\overline{3} \overline{6} 8$ \\
\hline R-squared & 0.320 & 0.324 & 0.423 & 0.581 & 0.575 & 0.573 \\
\hline
\end{tabular}

Note: Constant included but not reported. Year fixed effects included. Standard errors are reported below their coefficient estimates. ${ }^{*},{ }^{* *}$ and ${ }^{* * *}$ indicate statistical significance at the $10 \%, 5 \%$ and $1 \%$ levels, respectively. Specification (1) includes crisis dummy as control variable, specification (2) includes crisis dummy, inflation, and GDP growth as control variables, while specification (3) includes all control variables. Control variables are lagged one period. The Lerner index refers to the adjusted Lerner index proposed by Koetter et al. (2012). The Ushape test is based on Lind and Mehlum (2010) and the p-value of the test statistic is reported between square brackets. Ext. outside interval means that the extremum point (i.e. the turning point) is outside the interval, then we cannot reject the null hypothesis of a monotone relationship.

Finally, we investigate whether our results evolve when the same regression (equation 6) includes our two proxies for bank competition, which are the Lerner index and market share. As argued by Carbó et al. (2009), structural and nonstructural measures of competition tend to measure different things, and so they can be viewed as complementary proxies for competition. This is confirmed by the relatively low degree of correlation between the Lerner index and the market share for the Baltic countries (see figure 2). The results that we obtain when we consider the Lerner index, market share, and their squared terms in the same regression are reported in table 12. As is apparent, we still find a U-shaped relationship between bank competition and financial stability. 
Table 12: Market power and bank risk-taking: Results obtained with two proxies

\begin{tabular}{|c|c|c|c|c|c|c|}
\hline for competition in the same re & gression & $(2)$ & (3) & (1) & 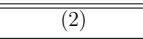 & (3) \\
\hline Dependent variable & $\begin{array}{c}\text { Z-score } \\
\text { FE }\end{array}$ & $\begin{array}{c}\text { Z-score } \\
\text { FE }\end{array}$ & $\begin{array}{c}\text { Z-score } \\
\text { FE }\end{array}$ & $\begin{array}{c}\text { Loan loss } \\
\text { FE }\end{array}$ & $\begin{array}{c}\text { Loan loss } \\
\text { FE }\end{array}$ & $\begin{array}{c}\text { Loan loss } \\
\text { FE }\end{array}$ \\
\hline Lerner & $\begin{array}{c}4.719^{* * *} \\
(1.139)\end{array}$ & $\begin{array}{c}4.742^{* * *} \\
(1.167)\end{array}$ & $\begin{array}{c}4.883^{* * *} \\
(1.213)\end{array}$ & $\begin{array}{c}-17.486^{* *} \\
(6.639)\end{array}$ & $\begin{array}{c}-17.898^{* *} \\
(6.808)\end{array}$ & $\begin{array}{c}-17.667^{* *} \\
(6.513)\end{array}$ \\
\hline Lerner*Lerner & $\begin{array}{c}-3.898^{* * * *} \\
(1.273)\end{array}$ & $\begin{array}{c}-3.970^{* * *} * \\
(1.330)\end{array}$ & $\begin{array}{c}-4.144^{* * * *} \\
(1.435)\end{array}$ & $\begin{array}{c}13.612^{*} \\
(8.003)\end{array}$ & $\begin{array}{c}14.713^{*} \\
(8.194)\end{array}$ & $\begin{array}{l}14.727^{*} \\
(8.297)\end{array}$ \\
\hline Market share & $\begin{array}{c}0.034 \\
(0.058)\end{array}$ & $\begin{array}{c}0.033 \\
(0.058)\end{array}$ & $\begin{array}{c}0.071 \\
(0.057)\end{array}$ & $\begin{array}{c}-1.633^{* * *} * \\
(0.582)\end{array}$ & $\begin{array}{c}-1.588^{* * *} \\
(0.573)\end{array}$ & $\begin{array}{c}-1.551^{* * *} \\
(0.486)\end{array}$ \\
\hline Market share*Market share & $\begin{array}{l}-0.000 \\
(0.001)\end{array}$ & $\begin{array}{l}-0.000 \\
(0.001)\end{array}$ & $\begin{array}{l}-0.000 \\
(0.001)\end{array}$ & $\begin{array}{c}0.016^{* *} \\
(0.006)\end{array}$ & $\begin{array}{c}0.015^{* *} \\
(0.006)\end{array}$ & $\begin{array}{c}0.015^{* * *} \\
(0.005)\end{array}$ \\
\hline U-shape test (Lerner) & $\begin{array}{c}1.97 \\
{[0.027]}\end{array}$ & $\begin{array}{c}1.93 \\
{[0.030]}\end{array}$ & $\begin{array}{c}1.88 \\
{[0.034]}\end{array}$ & $\begin{array}{c}0.95 \\
{[0.174]}\end{array}$ & $\begin{array}{c}1.11 \\
{[0.137]}\end{array}$ & $\begin{array}{c}1.07 \\
{[0.146]}\end{array}$ \\
\hline Turning point (Lerner) & 0.605 & 0.597 & 0.589 & - & - & - \\
\hline $95 \%$ confidence interval, Fieller method (Lerner) & {$[0.497 ; 0.995]$} & {$[0.485 ; 1.021]$} & {$[0.477 ; 1.067]$} & - & - & - \\
\hline U-shape test (Market share) & $\begin{array}{l}\text { Ext. outside } \\
\text { interval }\end{array}$ & $\begin{array}{l}\text { Ext. outside } \\
\text { interval }\end{array}$ & $\begin{array}{l}\text { Ext. outside } \\
\text { interval }\end{array}$ & $\begin{array}{l}\overline{2} . \overline{60}- \\
{[0.006]}\end{array}$ & $\begin{array}{c}2.52 \\
{[0.008]}\end{array}$ & $\begin{array}{c}\overline{2} . \overline{8} 2^{-} \\
{[0.003]}\end{array}$ \\
\hline Turning point (Market share) & - & - & - & 50.67 & 51.50 & 51.44 \\
\hline $95 \%$ confidence interval, Fieller method (Market share) & - & - & - & {$[45.99 ; 60.21]$} & {$[46.07 ; 63.65]$} & {$[46.14 ; 61.73]$} \\
\hline Observations & 350 & 350 & 346 & 349 & 349 & 349 \\
\hline R-squared & 0.435 & 0.436 & 0.457 & 0.646 & 0.656 & 0.665 \\
\hline Number of banks & 40 & 40 & 39 & 38 & 38 & 38 \\
\hline
\end{tabular}

Note: Constant included but not reported. Year fixed effects included. Robust standard errors clustered at bank level are reported below their coefficient estimates. *, ** and *** indicate statistical significance at the $10 \%, 5 \%$ and $1 \%$ levels, respectively. Specification (1) includes crisis dummy as control variable, specification (2) includes crisis dummy, inflation, and GDP growth as control variables, while specification (3) includes all control variables. Control variables are lagged one period. The Lerner index refers to the adjusted Lerner index proposed by Koetter et al. (2012). The U-shape test is based on Lind and Mehlum (2010) and the p-value of the test statistic is reported between square brackets. Ext. outside interval means that the extremum point (i.e. the turning point) is outside the interval, then we cannot reject the null hypothesis of a monotone relationship.

\section{Conclusion}

This paper is the first attempt to assess empirically the relationship between banking competition and financial stability in the Baltic countries. We do this using bank-level data and consider two alternative proxies for competition, the Lerner index and market share, with the Z-score and loan loss reserves as complementary measures of bank risk. We take a sample of 40 commercial banks in Estonia, Lithuania, and Latvia in 2000-2014, and our empirical results highlight an inverse and robust U-shaped relationship between the Lerner index and the Z-score, and a statistically significant U-shaped relationship between the Lerner index, market share and the loan loss reserves ratio. This means that a higher degree of market power arising from the low level of competition is associated with a decrease in risk-taking by banks and in the risk of insolvency for the banks up to a certain threshold, after which the relationship between competition and banking sector stability turns negative. We find that the optimal threshold for the Lerner index is 0.606 on average, and $49 \%$ is optimal for market share. The upper and lower values for the $95 \%$ confidence intervals are 0.508 and 0.873 for the Lerner index, and $39.46 \%$ and $55.41 \%$ for the market share.

The policy implications are that such a threshold implies that how the structure of the banking industry evolves is of critical importance for financial stability. 
This suggests that the policy-makers in charge of monitoring and regulating the banking industry should place greater emphasis on mergers and acquisitions, by encouraging them when competition is fierce, while preventing them in contrast in highly concentrated banking markets, at least for the largest banks.

This issue is especially important for the Baltic countries, which have a relatively high degree of concentration in the banking sector. As the low degree of correlation between the Lerner index and market share seems to suggest, permitting financial institutions to become larger might not necessarily lead to a lower degree of competition, but larger institutions might be encouraged to take more risk with their portfolios. Whatever the reason for financial institutions increasing risk, whether they are compensating for their improved diversification or exploiting their status as too big to fail, more attention should be devoted to the issue of the optimal size for them. 


\section{Appendix}

Table A1: Overview of bank-level analyses on the effect of bank competition on financial stability

\begin{tabular}{|c|c|c|c|c|}
\hline$\overline{P \text { Paper }}$ & Study area & Competition measure(s) & Dependent variable(s) & 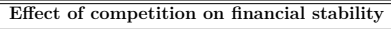 \\
\hline Agoraki et al. (2011) & CEECs & Lerner index & Z-score, Nonperforming loans (NPL) & Negative \\
\hline Almarzoqi et al. (2015) & MENA & Lerner index & Z-score, NPL & Negative \\
\hline Amidu and Wolfe (2013) & Emerging countries & Lerner index & Z-score, NPL, Capitalization ratio & Positive \\
\hline Anginer et al. (2014) & Mixed & Lerner index & Systemic risk measures & Positive \\
\hline Baselga-Pascual et al. (2015) & Euro area & Industry concentration & Z-score, NPL & Negative \\
\hline Beck et al. (2013) & Mixed & Lerner index & Z-score & Negative \\
\hline Berger et al. (2009) & Industrialised countries & Lerner, Industry concentration & Z-score, NPL, Capitalization ratio & Non-linear \\
\hline Buch et al. (2013) & Germany & Lerner index & Measure of bank distress & Negative \\
\hline Craig and Dinger (2013) & USA & Deposit market competition & NPL, ROA volatility, Stock price volatility & Positive \\
\hline Fiordelisi and Mare (2014) & $5 \mathrm{EU}$ countries & Lerner index & Z-score & Positive \\
\hline Forssbaeck and Shehzad (2015) & Mixed & Lerner index & Z-score & Negative \\
\hline Fu et al. (2014) & Asia Pacific & Lerner, Industry concentration & Z-score, Probability of bankruptcy & Ambiguous \\
\hline Fungáčová and Weill (2013) & Russia & Lerner index & Bank failure & Negative \\
\hline IJtsma et al. (2017) & $25 \mathrm{EU}$ countries & Industry concentration & Z-score & Positive \\
\hline Jeon and Lim (2013) & Korea & Boone index, Industry concentration & Z-score & Non-linear \\
\hline Jimenez et al. (2013) & Spain & Industry concentration & NPL & Non-linear \\
\hline Kasman and Kasman (2015) & Turkey & Lerner, Boone & Z-score, NPL & Non-linear \\
\hline Kick and Prieto (2015) & Germany & Market share, Lerner, Boone & Bank distress, Bank default & Ambiguous \\
\hline Kouki and Al-Nasser (2017) & Africa & Lerner index & Z-score & Negative \\
\hline Leroy and Lucotte (2017) & Europe & Lerner index & Z-score, Distance-to-default (DD), SRISK & Negative: Z-score \& DD, Positive: SRISK \\
\hline Liu and Wilson (2013) & Japan & Lerner index & Z-score & Non-linear \\
\hline Liu et al. (2013) & $10 \mathrm{EU}$ countries & Lerner index & Z-score & Non-linear \\
\hline Mirzaei et al. (2013) & Mixed & Bank market share, Industry concentration & Z-score & Ambiguous \\
\hline Saadaoui (2014) & Emerging countries & Lerner index & NPL & Negative \\
\hline Schaeck and Čihák (2014) & 10 EU countries & Boone index & Z-score & Positive \\
\hline Soedarmono et al. (2011) & Asia & Lerner index & Z-score & Positive \\
\hline Soedarmono et al. (2013) & Asia & Lerner index & Z-score & Positive \\
\hline Tabak et al. (2012) & Latin America & Boone index & Measure of 'stability efficiency' & Non-linear \\
\hline Tabak et al. (2013) & Latin America & Industry concentration & Measure of "stability efficiency' & Positive \\
\hline Tabak et al. (2015) & Brazil & H-statistic & Z-score, NPL & Negative \\
\hline Turk-Ariss (2010) & Developing countries & Lerner index & Z-score, Risk-adjusted rates of return & Negative \\
\hline
\end{tabular}

Table A2: Descriptive statistics

\begin{tabular}{lccccc}
\hline \hline Variable & Obs & Mean & Std. Dev. & Min & Max \\
\hline Lerner index & 401 & 0.48 & 0.29 & -0.05 & 0.97 \\
3-year MA Lerner index & 421 & 0.49 & 0.25 & -0.05 & 0.96 \\
Funding-adjusted Lerner index & 401 & 0.48 & 0.28 & 0.00 & 0.97 \\
Left-censored Lerner index & 401 & 0.49 & 0.28 & 0.00 & 0.97 \\
Market share & 410 & 10.93 & 16.03 & 0.00 & 80.72 \\
Global market share & 400 & 11.21 & 16.14 & 0.06 & 80.36 \\
Z-score & 370 & 2.74 & 1.50 & -2.99 & 7.27 \\
ZROE & 321 & 1.39 & 1.41 & -4.27 & 6.86 \\
Loan loss reserves & 390 & 5.69 & 8.30 & 0.00 & 78.97 \\
Impaired loans & 273 & 13.04 & 15.34 & 0.07 & 89.05 \\
Size & 410 & 13.52 & 1.79 & 6.65 & 17.45 \\
Non-interest income/total income & 410 & 0.45 & 0.24 & -0.67 & 2.73 \\
Fixed assets/total assets & 410 & 0.02 & 0.03 & 0.00 & 0.39 \\
Loans/total assets & 404 & 0.55 & 0.22 & 0.00 & 0.96 \\
Liquidity & 410 & 40.08 & 25.02 & 0.64 & 168.79 \\
Annual inflation rate & 600 & 3.79 & 3.57 & -1.15 & 15.43 \\
Annual GDP growth rate & 600 & 4.24 & 6.39 & -14.81 & 11.90 \\
\hline \hline
\end{tabular}


Table A3: Correlation matrix of bank-level variables

\begin{tabular}{lccccccc}
\hline \hline & var1 & var2 & var3 & var4 & var5 & var6 & var7 \\
\hline Lerner (var1) & 1 & & & & & & \\
Market share (var2) & $0.1671^{*}$ & 1 & & & & & \\
Size (var3) & 0.0674 & $0.6271^{*}$ & 1 & & & & \\
Non-interest income/total income (var 4) & $-0.1654^{*}$ & $-0.1098^{*}$ & $-0.1529^{*}$ & 1 & & & \\
Fixed assets/total assets (var 5) & -0.0960 & $-0.0982^{*}$ & $-0.4610^{*}$ & $0.2992^{*}$ & 1 & & \\
Loans/total assets (var6) & $0.1006^{*}$ & $0.3239^{*}$ & $0.4353^{*}$ & $-0.4343^{*}$ & $-0.1720^{*}$ & 1 & \\
Liquidity (var7) & 0.0529 & $-0.2554^{*}$ & $-0.4303^{*}$ & $0.3233^{*}$ & $0.2119^{*}$ & $-0.8161^{*}$ & 1 \\
\hline \hline
\end{tabular}

Note: ${ }^{*}$ indicates statistical significance at the $5 \%$ level.

Table A4: Definition and source of variables

\begin{tabular}{|c|c|}
\hline Variable & Definition \\
\hline \multicolumn{2}{|l|}{ Dependent variables } \\
\hline Z-score & $\begin{array}{l}\text { Accounting bank-level measure of individual bank risk. A larger value indicates a higher bank stability and less } \\
\text { bank risk-taking. Source: Authors' calculations, Bankscope }\end{array}$ \\
\hline ZROE & $\begin{array}{l}\text { Return-on-equity based Z-score measure. A larger value indicates a higher bank stability and less bank risk-taking. } \\
\text { Source: Authors' calculations, Bankscope }\end{array}$ \\
\hline Loan loss reserves & $\begin{array}{l}\text { Ratio indicating how much of the total portfolio of a bank has been provided for but not charged off. } \\
\text { It is a reserve for losses expressed as percentage of total loans. Given a similar charge-off policy the higher the ratio } \\
\text { the poorer the quality of the loan portfolio is. Source: Bankscope }\end{array}$ \\
\hline Impaired loans & $\begin{array}{l}\text { Impaired loans (or non-performing loans) are loans that are unlikely to be paid back for the full amount. } \\
\text { The impaired loans to gross loans ratio is used to measure bank's asset risk. Source: Bankscope }\end{array}$ \\
\hline \multicolumn{2}{|r|}{ 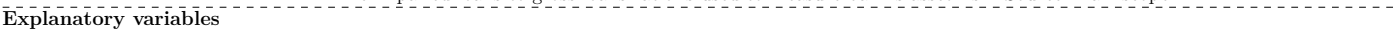 } \\
\hline Lerner index & $\begin{array}{l}\text { A bank-level measure of bank market power following the methodology proposed by Koetter et al. (2012). A higher value } \\
\text { indicates more market power and less bank competition. Source: Authors' calculations, Bankscope }\end{array}$ \\
\hline 3-year MA Lerner index & $\begin{array}{l}\text { A 3-year rolling time window is used to compute the Lerner index. A higher value indicates more market } \\
\text { power and less bank competition. Source: Authors' calculations, Bankscope }\end{array}$ \\
\hline Funding-adjusted Lerner index & $\begin{array}{l}\text { Following Maudos and de Guevara (2007), a two-input cost function is considered to estimate the translog cost } \\
\text { function. A higher value of the funding-adjusted Lerner index indicates more market power and less bank competition. } \\
\text { Source: Authors' calculations, Bankscope }\end{array}$ \\
\hline Left-censored Lerner index & $\begin{array}{l}\text { Negative values of the Lerner index are truncated to zero. A higher value of the left-censored Lerner } \\
\text { index indicates more market power and less bank competition. Source: Authors' calculations, Bankscope }\end{array}$ \\
\hline Bank size & The $\log$ value of total assets. Source: BankScope \\
\hline Non-interest income / Total income & A bank-level measure of business diversification. Source: Bankscope \\
\hline Fixed assets / Total assets & A bank-level measure of asset composition. Source: Bankscope \\
\hline Liquidity & $\begin{array}{l}\text { A bank-level liquidity indicator, which corresponds to the ratio of liquid assets over deposits and } \\
\text { short term funding. A higher value indicates less liquidity risk. Source: Bankscope }\end{array}$ \\
\hline Loans / Total assets & A bank-level measure of asset composition. Source: Bankscope \\
\hline GDP growth & Annual real GDP growth. Source: World Development Indicators (WDI), World Bank \\
\hline Inflation & Annual percentage change of consumer prices index. Source: World Development Indicators (WDI), World Bank \\
\hline
\end{tabular}


Figure A5: Conditional marginal effects

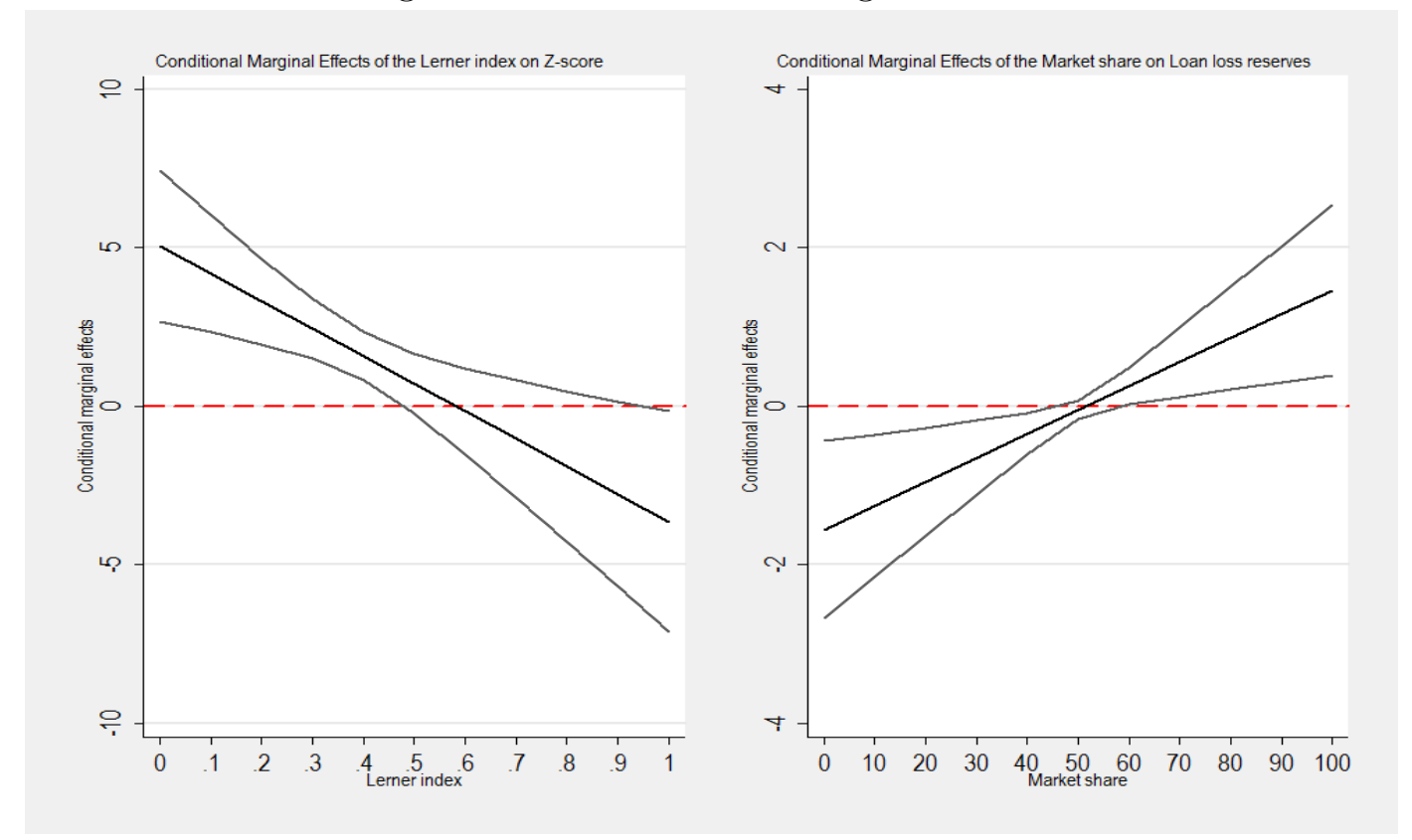

Note: The conditional marginal effects are computed by considering our benchmark nonlinear specification estimated using the fixed effects (FE) estimator, i.e. the specification (3) in table 4 for the Lerner index, and the specification (3) in table 7 for the market share. The Lerner index refers to the adjusted Lerner index proposed by Koetter et al. (2012). The grey lines correspond to the $95 \%$ confidence interval. 
Figure A6: Average turning points and situation of banks in Baltic countries
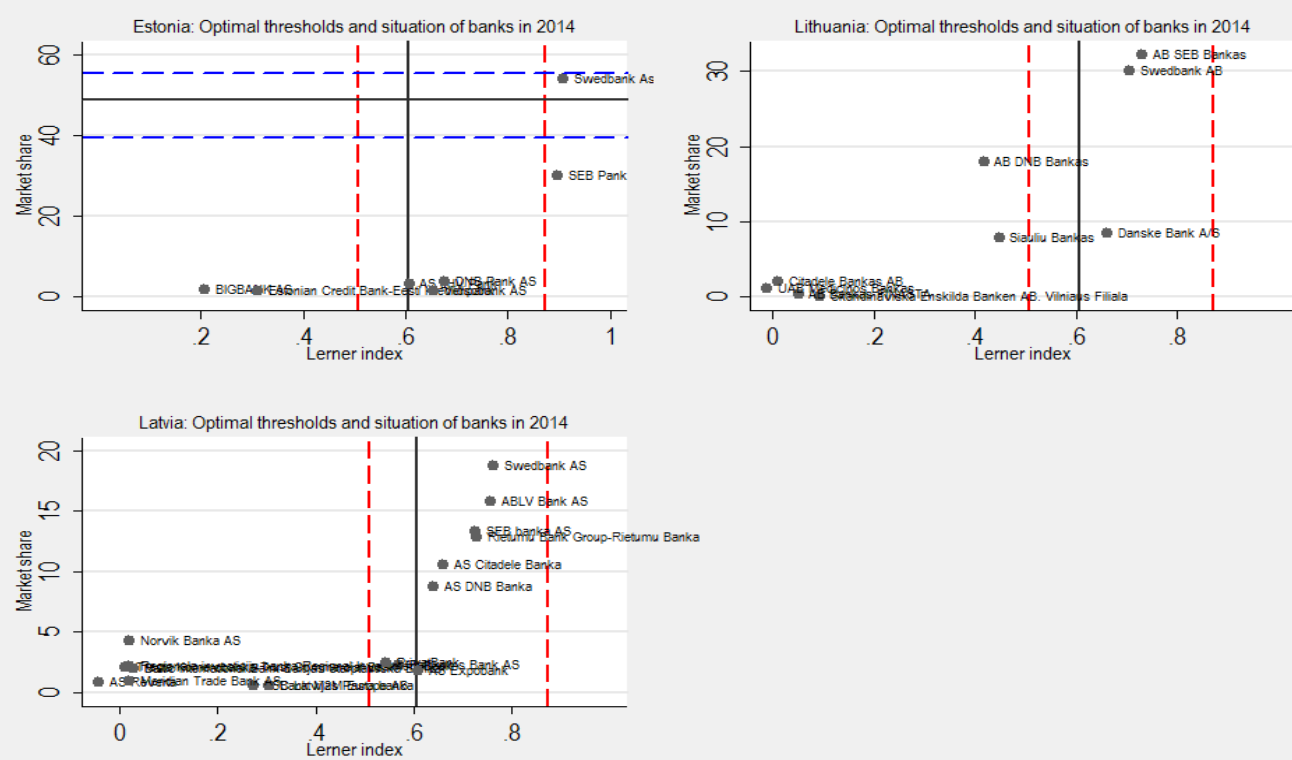

Note: The average turning point for the Lerner index and the market share is calculated by considering results obtained with our benchmark nonlinear specification, i.e. results reported in tables 4, 5, 6 and 7. Also note that we only consider the specifications for which the Ushape test indicates a p-value below 0.05. The average "optimal" threshold for the Lerner index is equal to 0.606 , and to $49 \%$ for the market share. The Lerner index refers to the adjusted Lerner index proposed by Koetter et al. (2012). The red dash line corresponds to the $95 \%$ confidence interval for the Lerner index, while the blue dash line corresponds to the 95\% confidence interval for the market share. More precisely, the confidence intervals reported in this graph correspond to the average of the upper and lower confidence bounds calculated by considering all specifications for which the U-shape test indicates a non-linear relationship statistically significant at the $5 \%$ level. 
Figure A7: Histogram and kernel density plot of the Lerner index


Note: The Lerner index refers to the adjusted Lerner index proposed by Koetter et al. (2012).

Figure A8: Histogram and kernel density plot of the market share
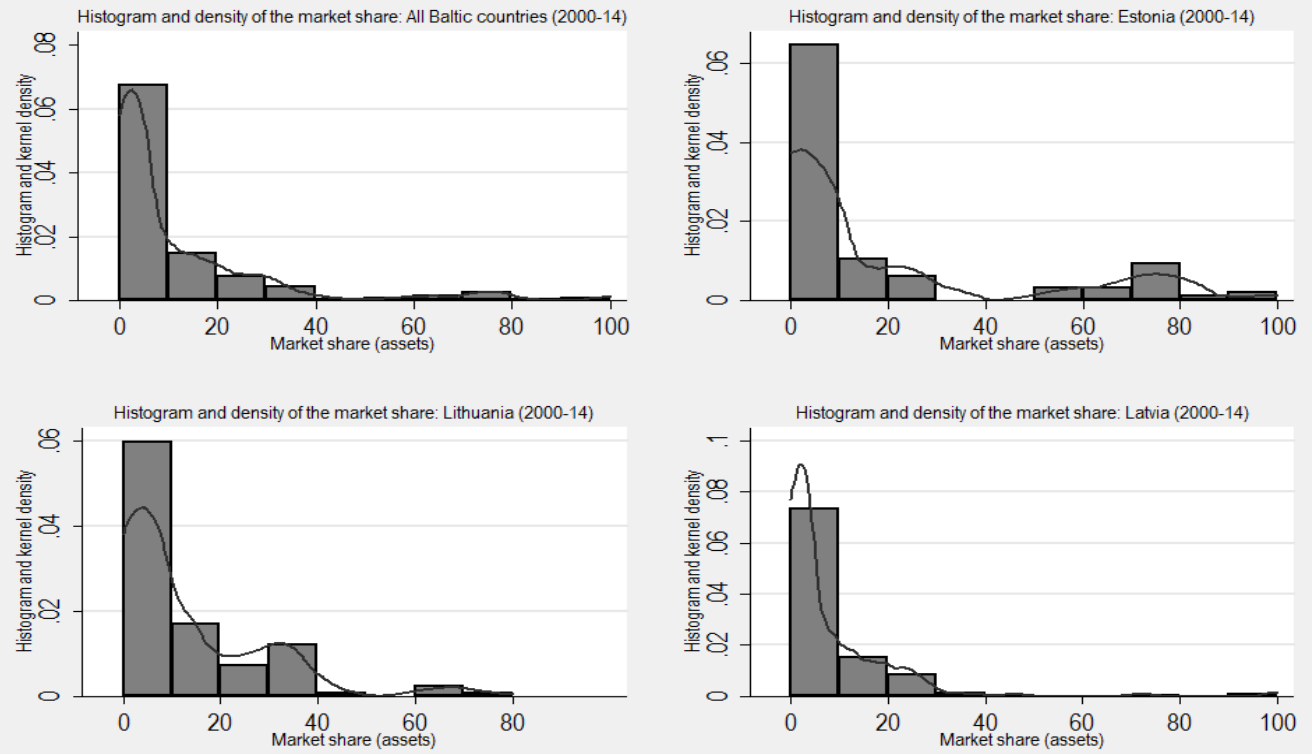
Figure A9: Correlation between alternative measures of market power for each Baltic country
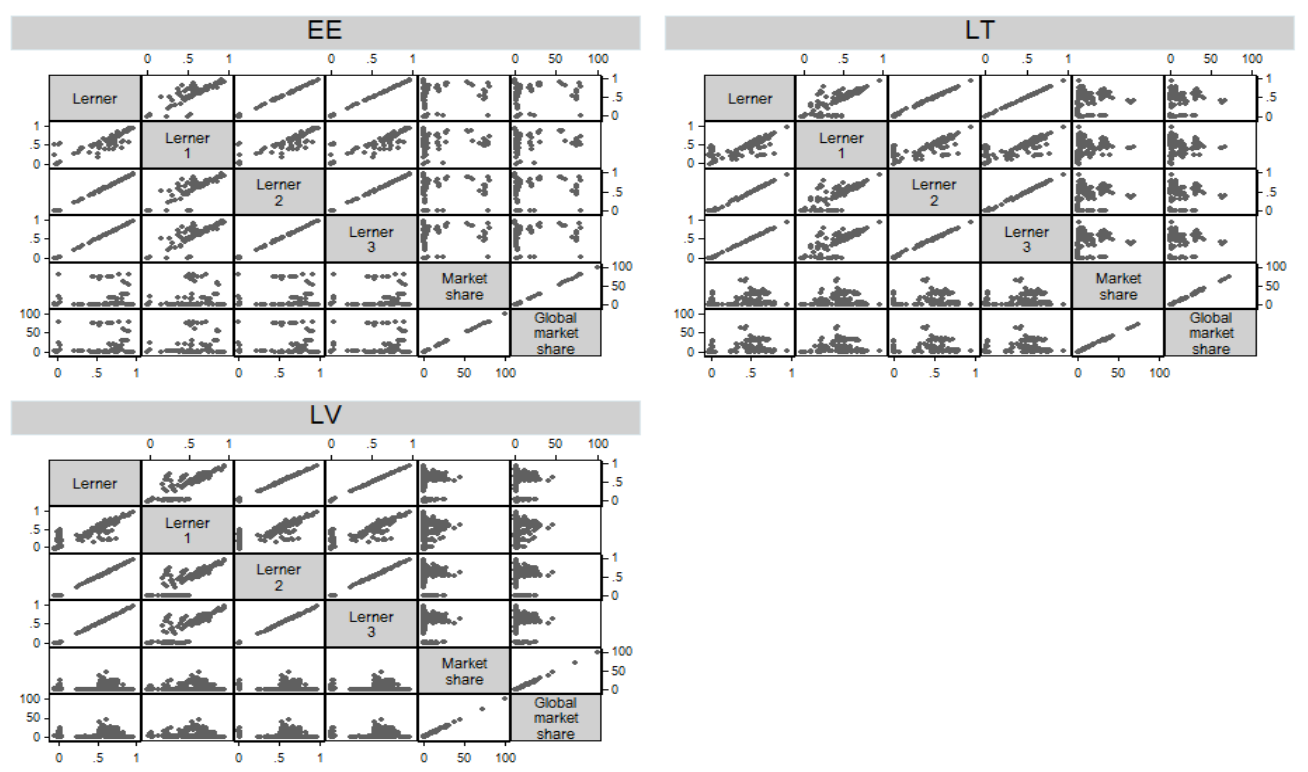

Note: EE: Estonia; LT: Lithuania; LV: Latvia. Lerner refers to the adjusted Lerner index proposed by Koetter et al. (2012), Lerner 1 to the 3-year moving average Lerner index, Lerner 2 to the funding-adjusted Lerner index, Lerner 3 to the left-censored Lerner index, Market share to the market share based on assets, and global market share to the market share calculated by considering assets, loans and deposits. 


\section{Bibliography}

Agoraki, M.-E. K., Delis, M. D., and Pasiouras, F. (2011). Regulations, competition and bank risk-taking in transition countries. Journal of Financial Stability, 7(1):38-48.

Allen, F. and Gale, D. (2000). Comparing financial systems. MIT Press, Cambridge, MA.

Almarzoqi, R., Naceur, S. B., and Scopelliti, A. (2015). How Does Bank Competition Affect Solvency, Liquidity and Credit Risk? Evidence from the MENA Countries. IMF Working Papers 15/210, International Monetary Fund.

Amidu, M. and Wolfe, S. (2013). Does bank competition and diversification lead to greater stability? evidence from emerging markets. Review of Development Finance, 3(3):152 - 166.

Anginer, D., Demirguc-Kunt, A., and Zhu, M. (2014). How does competition affect bank systemic risk? Journal of Financial Intermediation, 23(1):1-26.

Bain, J. S. (1959). Industrial Organization. John Wiley and Sons, New York.

Baselga-Pascual, L., Trujillo-Ponce, A., and Cardone-Riportella, C. (2015). Factors influencing bank risk in Europe: Evidence from the financial crisis. The North American Journal of Economics and Finance, 34:138 - 166.

Beck, T. (2008). Bank competition and financial stability : friends or foes ? Policy Research Working Paper Series 4656, The World Bank.

Beck, T., Demirgüc-Kunt, A., and Levine, R. (2006). Bank concentration, competition, and crises: First results. Journal of Banking $\&$ Finance, 30(5):15811603.

Beck, T., Jonghe, O. D., and Schepens, G. (2013). Bank competition and stability: Cross-country heterogeneity. Journal of Financial Intermediation, $22(2): 218-244$.

Bergantino, A. S. and Capozza, C. (2013). The effect of bank concentration on entrepreneurship in Central and Eastern European Transition Countries. ERSA conference papers 13, European Regional Science Association.

Berger, A. N. (1995). The profit-structure relationship in banking-tests of market-power and efficient-structure hypotheses. Journal of Money, Credit and Banking, 27(2):404-431.

Berger, A. N. and Hannan, T. H. (1998). The Efficiency Cost Of Market Power In The Banking Industry: A Test Of The "Quiet Life" And Related Hypotheses. The Review of Economics and Statistics, 80(3):454-465. 
Berger, A. N., Klapper, L. F., and Turk-Ariss, R. (2009). Bank competition and financial stability. Journal of Financial Services Research, 35(2):99-118.

Bikker, J. A. and Haaf, K. (2002). Competition, concentration and their relationship: An empirical analysis of the banking industry. Journal of Banking Ef Finance, 26(11):2191 - 2214.

Boone, J. (2008). A New Way to Measure Competition. Economic Journal, 118(531):1245-1261.

Boot, W. A. and Greenbaum, S. I. (1993). Bank regulation, reputation and rents: Theory and policy implications. In Capital Markets and Financial Intermediation. Cambridge University Press, Cambridge.

Boyd, J. H. and De Nicoló, G. (2005). The Theory of Bank Risk Taking and Competition Revisited. The Journal of Finance, 60(3):1329-1343.

Boyd, J. H., De Nicolo, G., and Jalal, A. M. (2006). Bank risk-taking and competition revisited: New theory and new evidence. IMF Working paper WP/06/297, International Monetary Fund.

Boyd, J. H. and Runkle, D. E. (1993). Size and performance of banking firms. Journal of Monetary Economics, 31(1):47 - 67.

Buch, C. M., Koch, C. T., and Koetter, M. (2013). Do banks benefit from internationalization? revisiting the market power-risk nexus. Review of Finance, 17(4):1401.

Caminal, R. and Matutes, C. (2002). Market power and banking failures. International Journal of Industrial Organization, 20(9):1341-1361.

Carbó, S., Humphrey, D., Maudos, J., and Molyneux, P. (2009). Cross-country comparisons of competition and pricing power in european banking. Journal of International Money and Finance, 28(1):115 - 134.

Cifter, A. (2015). Bank concentration and non-performing loans in Central and Eastern European countries. Journal of Business Economics and Management, 16(1):117-137.

Claessens, S. and Laeven, L. (2004). What drives bank competition? some international evidence. Journal of Money, Credit and Banking, 36(3):563-583.

Craig, B. R. and Dinger, V. (2013). Deposit market competition, wholesale funding, and bank risk. Journal of Banking \& Finance, 37(9):3605 - 3622.

Demsetz, H. (1973). Industry structure, market rivalry, and public policy. The Journal of Law and Economics, 16(1):1-9.

Diallo, B. (2015). Bank competition and crises revisited: New results. Economics Letters, 129:81-86. 
Evanoff, D. D. and Fortier, D. L. (1988). Reevaluation of the structure-conductperformance paradigm in banking. Journal of Financial Services Research, 1(3):277-294.

Fiordelisi, F. and Mare, D. S. (2014). Competition and financial stability in European cooperative banks. Journal of International Money and Finance, $45: 1-16$

Forssbaeck, J. and Shehzad, C. T. (2015). The Conditional Effects of Market Power on Bank Risk-Cross-Country Evidence. Review of Finance, 19(5):1997-2038.

Fu, X. M., Lin, Y. R., and Molyneux, P. (2014). Bank competition and financial stability in Asia Pacific. Journal of Banking 6 Finance, 38:64 - 77.

Fungáčová, Z. and Weill, L. (2013). Does competition influence bank failures? Economics of Transition, 21(2):301-322.

Gutiérrez de Rozas, L. (2007). Testing for competition in the Spanish banking industry: The Panzar-Rosse approach revisited. Working Papers 0726, Banco de España.

Hicks, J. R. (1935). Annual survey of economic theory: The theory of monopoly. Econometrica, 3(1):1-20.

IJtsma, P., Spierdijk, L., and Shaffer, S. (2017). The Concentration-Stability Controversy in Banking: New Evidence from the EU-25. Journal of Financial Stability, pages -.

Jeon, J. Q. and Lim, K. K. (2013). Bank competition and financial stability: A comparison of commercial banks and mutual savings banks in Korea. PacificBasin Finance Journal, 25:253 - 272.

Jimenez, G., Lopez, J. A., and Saurina, J. (2013). How does competition affect bank risk-taking? Journal of Financial Stability, 9(2):185-195.

Kasman, S. and Kasman, A. (2015). Bank competition, concentration and financial stability in the Turkish banking industry. Economic Systems, 39(3):502517. Symposium: Financial System and Development in China.

Keeley, M. C. (1990). Deposit insurance, risk, and market power in banking. The American Economic Review, 80(5):1183-1200.

Kick, T. and Prieto, E. (2015). Bank Risk and Competition: Evidence from Regional Banking Markets. Review of Finance, 19(3):1185-1222.

Koetter, M., Kolari, J. W., and Spierdijk, L. (2012). Enjoying the quiet life under deregulation? Evidence from adjusted Lerner indices for U.S. banks . Review of Economics and Statistics, 94(2):462-480. 
Kouki, I. and Al-Nasser, A. (2017). The implication of banking competition: Evidence from African countries. Research in International Business and Finance, 39, Part B:878 - 895 .

Lapteacru, I. (2014). Do more competitive banks have less market power? The evidence from Central and Eastern Europe. Journal of International Money and Finance, 46(C):41-60.

Lepetit, L. and Strobel, F. (2013). Bank insolvency risk and time-varying Zscore measures. Journal of International Financial Markets, Institutions and Money, 25:73-87.

Lerner, A. P. (1934). The Concept of Monopoly and the Measurement of Monopoly Power. Review of Economic Studies, 1(3):157-175.

Leroy, A. and Lucotte, Y. (2017). Is there a competition-stability trade-off in European banking? Journal of International Financial Markets, Institutions and Money, 46:199 - 215 .

Lind, J. T. and Mehlum, H. (2010). With or without $\mathrm{u}$ ? the appropriate test for a u-shaped relationship. Oxford Bulletin of Economics and Statistics, 72(1):109118.

Liu, H., Molyneux, P., and Wilson, J. O. S. (2013). Competition and stability in European banking: A regional analysis. The Manchester School, 81(2):176201.

Liu, H. and Wilson, J. O. (2013). Competition and risk in Japanese banking. The European Journal of Finance, 19(1):1-18.

Marcus, A. J. (1984). Deregulation and bank financial policy. Journal of Banking \& Finance, 8(4):557-565.

Martinez-Miera, D. and Repullo, R. (2010). Does Competition Reduce the Risk of Bank Failure? Review of Financial Studies, 23(10):3638-3664.

Mason, E. S. (1939). Price and production policies of large-scale enterprise. The American Economic Review, 29(1):61-74.

Maudos, J. and de Guevara, J. F. (2007). The cost of market power in banking: Social welfare loss vs. cost inefficiency. Journal of Banking $\mathscr{G}$ Finance, 31(7):2103 - 2125. Developments in European Banking.

Mirzaei, A., Moore, T., and Liu, G. (2013). Does market structure matter on banks' profitability and stability? emerging vs. advanced economies. Journal of Banking Ef Finance, 37(8):2920 - 2937.

Mishkin, F. (1999). Financial consolidation: Dangers and opportunities. Journal of Banking \& Finance, 23(2-4):675-691. 
Northcott, C. A. (2004). Competition in Banking: A Review of the Literature. Staff Working Papers 04-24, Bank of Canada.

Panzar, J. C. and Rosse, J. N. (1987). Testing for "monopoly" equilibrium. The Journal of Industrial Economics, 35(4):443-456.

Peltzman, S. (1977). The gains and losses from industrial concentration. The Journal of Law and Economics, 20(2):229-263.

Saadaoui, Z. (2014). Business cycle, market power and bank behaviour in emerging countries. International Economics, 139:109 - 132.

Schaeck, K. and Čihák, M. (2008). How does competition affect efficiency and soundness in banking? New empirical evidence. Working Paper Series 0932, European Central Bank.

Schaeck, K. and Čihák, M. (2014). Competition, efficiency, and stability in banking. Financial Management, 43(1):215-241.

Schaeck, K., Čihák, M., and Wolfe, S. (2009). Are competitive banking systems more stable? Journal of Money, Credit and Banking, 41(4):711-734.

Smirlock, M. (1985). Evidence on the (non) relationship between concentration and profitability in banking. Journal of Money, Credit and Banking, 17(1):6983 .

Soedarmono, W., Machrouh, F., and Tarazi, A. (2011). Bank market power, economic growth and financial stability: Evidence from Asian banks. Journal of Asian Economics, 22(6):460 - 470.

Soedarmono, W., Machrouh, F., and Tarazi, A. (2013). Bank competition, crisis and risk taking: Evidence from emerging markets in Asia. Journal of International Financial Markets, Institutions and Money, 23:196 - 221.

Tabak, B. M., Fazio, D. M., and Cajueiro, D. O. (2012). The relationship between banking market competition and risk-taking: Do size and capitalization matter? Journal of Banking $\&$ Finance, 36(12):3366 - 3381. Systemic risk, Basel III, global financial stability and regulation.

Tabak, B. M., Fazio, D. M., and Cajueiro, D. O. (2013). Systemically important banks and financial stability: The case of Latin America. Journal of Banking Ef Finance, 37(10):3855 - 3866.

Tabak, B. M., Gomes, G. M., and da Silva Medeiros, M. (2015). The impact of market power at bank level in risk-taking: The Brazilian case. International Review of Financial Analysis, 40:154 - 165.

Turk-Ariss, R. (2010). On the implications of market power in banking: Evidence from developing countries. Journal of Banking \& Finance, 34(4):765 - 775. 
Uhde, A. and Heimeshoff, U. (2009). Consolidation in banking and financial stability in Europe: Empirical evidence. Journal of Banking $\&$ Finance, 33(7):1299 - 1311 . 